\title{
After the extreme flood in 2002: changes in preparedness, response and recovery of flood-affected residents in Germany between 2005 and 2011
}

\author{
S. Kienzler ${ }^{1}$, I. Pech ${ }^{1}$, H. Kreibich ${ }^{2}$, M. Müller ${ }^{3}$, and A. H. Thieken ${ }^{1}$ \\ ${ }^{1}$ Institute of Earth and Environmental Science, University of Potsdam, Karl-Liebknecht-Strasse 24-25, \\ 14476 Potsdam-Golm, Germany \\ ${ }^{2}$ Department of Hydrology, German Research Centre for Geosciences, Telegrafenberg, 14473 Potsdam, Germany \\ ${ }^{3}$ Deutsche Rückversicherung AG, Hansaallee 177, 40549 Düsseldorf, Germany
}

Correspondence to: S. Kienzler (kienzler@uni-potsdam.de)

Received: 22 August 2014 - Published in Nat. Hazards Earth Syst. Sci. Discuss.: 9 October 2014

Revised: 11 February 2015 - Accepted: 15 February 2015 - Published: 10 March 2015

\begin{abstract}
In the aftermath of the severe flooding in Central Europe in August 2002, a number of changes in flood policies were launched in Germany and other European countries, aiming at improved risk management. The question arises as to whether these changes have already had an impact on the residents' ability to cope with floods, and whether flood-affected private households are now better prepared than they were in 2002. Therefore, computer-aided telephone interviews with private households in Germany that suffered from property damage due to flooding in 2005, 2006, 2010 or 2011 were performed and analysed with respect to flood awareness, precaution, preparedness and recovery. The data were compared to a similar investigation conducted after the flood in 2002.

After the flood in 2002, the level of private precautions taken increased considerably. One contributing factor is the fact that, in general, a larger proportion of people knew that they were at risk of flooding. The best level of precaution was found before the flood events in 2006 and 2011. The main reason for this might be that residents had more experience with flooding than residents affected in 2005 or 2010. Yet, overall, flood experience and knowledge did not necessarily result in building retrofitting or flood-proofing measures, which are considered as mitigating damages most effectively. Hence, investments still need to be stimulated in order to reduce future damage more efficiently.

Early warning and emergency responses were substantially influenced by flood characteristics. In contrast to floodaffected people in 2006 or 2011, people affected by flood-
\end{abstract}

ing in 2005 or 2010 had to deal with shorter lead times and therefore had less time to take emergency measures. Yet, the lower level of emergency measures taken also resulted from the people's lack of flood experience and insufficient knowledge of how to protect themselves. Overall, it was noticeable that these residents suffered from higher losses. Therefore, it is important to further improve early warning systems and communication channels, particularly in hilly areas with rapid-onset flooding.

\section{Introduction}

In August 2002, a severe flood event occurred in Central Europe (Germany, Austria, the Czech Republic and Slovakia), which was associated with a $\mathrm{Vb}$ weather situation. $\mathrm{On} \mathrm{a} \mathrm{Vb}$ track, cyclones transport warm and moist air from the Adriatic region in the northeast direction across Austria and the Czech Republic towards Poland. Once the air reaches the low mountain ranges (e.g. Ore Mountains), it is lifted and cools down. This leads to large-scale, orographic-induced rainfall, which may cause severe summer floods (Mudelsee et al., 2004). In August 2002, heavy precipitation with recordbreaking amounts, e.g. of $312 \mathrm{~mm}$ within $24 \mathrm{~h}$, had been observed at the gauging station Zinnwald-Georgenfeld in the Ore Mountains, Germany, and resulted in high discharges and water levels in the rivers Elbe and Danube and some of their tributaries (see Ulbrich et al., 2003; Engel, 2004). 
The high hydraulic impact led to the activation of dam spillways, as well as to the overtopping and breaching of embankments in many places. Among other aspects, missing or incomplete flood warnings, bad maintenance of flood protection structures, as well as a lack of knowledge about appropriate behaviour were identified as weaknesses of the flood risk management (DKKV, 2003; Thieken et al., 2007). Altogether, 21 people were killed in Germany and the total damage amounted to EUR 11.6 billion (reference year 2005, Thieken et al., 2006). This amount far exceeded the damages of former disastrous events and, despite a similar flood event in June 2013, it is still the highest damage record in Germany (EM-DAT, 2014). After the flood in 2002, many activities were launched on the administrative and legislative levels (see DKKV, 2003). In particular, the German act on precautionary flood protection in 2005 ("Artikelgesetz zur Verbesserung des vorbeugenden Hochwasserschutzes") and the European Floods Directive (2007/EC/60; EC, 2007) were important policies which also indicated a shift from a pure technically-oriented flood defence towards a more integrated flood risk management that also considers non-structural measures to minimize adverse effects of flooding. In general, flood risk management focuses on three aspects (Vis et al., 2003): (1) flood abatement with the aim of preventing peak flows, e.g. through an improvement of the water retention capacities in the whole catchment; (2) flood control that is aimed at preventing inundation by structural measures, e.g. embankments or detention areas; and, (3) flood alleviation with the goal to reduce flood impacts through non-structural measures (Parker, 2000; de Bruijn, 2005). In the latter, preventive, precautionary and preparative measures can be distinguished. Prevention is aimed at completely avoiding damage in hazard-prone areas, e.g. by land-use regulation. Precaution and preparation help to limit and manage the adverse effects of a catastrophe and to strengthen coping capacities through flood-resilient design and construction, development of early warning systems, awareness campaigns, education and training, etc. (e.g. Vis et al., 2003; DKKV, 2003; PLANAT, 2004; de Bruijn, 2005). If damage occurs despite these measures, risk transfer mechanisms such as flood insurance help to accelerate recovery (see e.g. Thieken et al., 2006; Schwarze et al., 2011).

The success of precautionary and preparatory measures is influenced by the risk awareness and preparedness of floodaffected residents. It is assumed that people are motivated to take precautionary measures and mitigate losses if they perceive their flood risk as high (motivational hypothesis, Weinstein et al., 1998). In this study, the term "risk awareness" only refers to the individual's perceived probability of being personally affected by a future flood event. Risk awareness and private precaution are, in turn, positively influenced by flood experience. This is also confirmed by Bubeck et al. (2012a) and Kuhlicke et al. (2014). In this context, surveys which were performed a few months after the flood in 2002 (Thieken et al., 2005; Kreibich et al., 2007) revealed that flood-affected households and companies had difficulties coping with the flooding and suffered from high financial losses, particularly along the river Elbe and its tributaries. In these areas, only 4 and $7 \%$, respectively, had experienced flooding in the ten years prior to the event (Thieken et al., 2007). Hence, flood risk awareness and private precaution were at a low level.

After the flood in 2002, a substantial increase in the implementation of precautionary measures was detected for private households and companies (Thieken et al., 2007; Kreibich et al., 2005, 2007, 2011). Therefore, the question arises whether German residents at risk of flooding are now better able to cope with flooding than they were in 2002. Since the abovementioned changes in European and national flood policies have not only been effective in the regions affected in 2002 but also in all of Germany, flood risk awareness and preparedness should have increased in general, i.e. also in areas that did not experience flooding recently. This aspect will be addressed in this paper by investigating the coping capacities of private households during four flood events between 2005 and 2011 that occurred in different regions. Analogous to the paper by Thieken et al. (2007), the disaster management cycle will be used as a framework for the analysis. The cycle has been used widely by international and national organisations, and various versions have been published (e.g. Silver, 2001; DKKV, 2003; PLANAT, 2004; FEMA, 2004; Kienholz et al., 2004). The cycle we consider distinguishes three phases:

- (emergency) response: during the event, immediate measures are taken with the priority placed on limiting the adverse effects and duration of the event;

- recovery: after the event, the affected society starts to repair the damage and to regain the same or a similar standard of living than before the disaster happened;

- disaster risk reduction: in this period, measures are planned and implemented that aim to minimize the vulnerability of people and their assets.

Other cycle versions sometimes distinguish a fourth phase - risk analysis and event assessment - which ideally accompanies the recovery phase and then leads to the phase of disaster risk reduction (Kienholz et al., 2004).

This paper aims to reveal how residents in different regions of Germany were prepared for the recent flooding, how they responded to the hazardous events, how they suffered in terms of financial damage and recovered, as well as what they changed in precautionary measures after having experienced a flood. We focus on four flood events in Germany that happened in August 2005, March/April 2006, August 2010 and January 2011, respectively. The four events affected different catchment areas: in 2005 and 2006, the flooded regions were similar to those in 2002. In 2010 and 2011, however, flooding occurred in regions where fewer people experienced 
Table 1. Hydro-meteorological conditions and financial damage for the investigated flood events.

\begin{tabular}{|c|c|c|c|c|c|}
\hline Flood event & August 2002 & August 2005 & March/April 2006 & August 2010 & January 2011 \\
\hline $\begin{array}{l}\text { Affected river } \\
\text { catchments }\end{array}$ & Danube, Elbe & Danube, Elbe & Elbe, Danube & Elbe, Oder & $\begin{array}{l}\text { Rhine, Danube, } \\
\text { Elbe, Oder, Weser }\end{array}$ \\
\hline $\begin{array}{l}\text { Preconditions } \\
\text { and } \\
\text { meteorological } \\
\text { causes }\end{array}$ & $\begin{array}{l}\text { High preceding } \\
\text { soil moisture was } \\
\text { followed by a Vb } \\
\text { weather system } \\
\text { with extensive } \\
\text { rainfall in Austria, } \\
\text { the Czech } \\
\text { Republic, Slovakia } \\
\text { and Germany }\end{array}$ & $\begin{array}{l}\text { Reduced snow } \\
\text { cover formation } \\
\text { due to mild } \\
\text { temperatures in } \\
\text { the Alpine region } \\
\text { and high preceding } \\
\text { soil moisture } \\
\text { were followed by a } \\
\text { Vb weather system } \\
\text { with extensive } \\
\text { rainfall in Austria, } \\
\text { Switzerland and } \\
\text { Germany }\end{array}$ & $\begin{array}{l}\text { Complete } \\
\text { snowmelt due } \\
\text { to rapid } \\
\text { temperature } \\
\text { increase, } \\
\text { accompanied by } \\
\text { heavy rainfall from } \\
\text { westerly cyclones }\end{array}$ & $\begin{array}{l}\text { Three consecutive } \\
\text { fronts (classical } \\
\text { Vb weather } \\
\text { system track but not } \\
\text { classical formation) } \\
\text { with heavy rainfall; } \\
\text { flooding was } \\
\text { intensified by a dam } \\
\text { breach at the Witka } \\
\text { river }\end{array}$ & $\begin{array}{l}\text { Extensive } \\
\text { snowmelt } \\
\text { due to rapid } \\
\text { temperature } \\
\text { increase and heavy } \\
\text { rainfall followed by } \\
\text { more intense } \\
\text { rainfall }\end{array}$ \\
\hline Damage & $\begin{array}{l}\text { EUR } 11.6 \text { billion } \\
\text { (reference year } \\
\text { 2005) } \\
\text { (Thieken et al., } \\
\text { 2006) }\end{array}$ & $\begin{array}{l}\text { EUR } 175 \text { million } \\
\text { (Kron, 2009) }\end{array}$ & $\begin{array}{l}\text { EUR } 120 \text { million } \\
\text { (Kron and } \\
\text { Ellenrieder, 2008) }\end{array}$ & $\begin{array}{l}\text { EUR } 839 \text { million } \\
(\mathrm{EC}, 2014)\end{array}$ & $\begin{array}{l}\text { More than } \\
\text { EUR } 100 \text { million } \\
\text { (Axer et al., 2012) }\end{array}$ \\
\hline
\end{tabular}

a flood within the last ten years, although in some areas in the Rhine catchment the level of precaution was assumed to be high (Bubeck et al., 2012b). In addition, these floods were triggered by different weather patterns. While flooding in 2005 and 2010 was, like in 2002, due to heavy precipitation in connection with a $\mathrm{Vb}$ weather type, floods in 2006 and 2011 were characterized by a "rain on snow" mechanism. Since the level of preparedness and reaction might also depend on the flood characteristics, the four flood events will be described in more detail in the next section. In Sect. 3, data and methods of the analysis will be introduced. Then, Sect. 4 focuses on the results of the analyses, while Sect. 5 offers some conclusions on what could further be done to enforce private precaution and disaster preparedness.

In addition, it should be noted that damage figures quoted in the text always apply for the respective flood year if no explicit reference year is provided. With regard to figures from our surveys, we referred all values and losses to the year 2013. To allow for comparison with figures from the literature, we provided both figures (i.e. loss in the event year and referenced to the year 2013).

\section{The four flood events}

In order to provide a basis for the interpretation of flood characteristics alongside the reaction and coping capacities of affected residents, the four flood events are described in this section. A description of the 2002 event that serves as a reference (see Sect. 3.1, Table 2) was already given in the intro- duction. Table 1 summarizes the hydro-meteorological conditions and financial damages of all flood events. The rivers and cities mentioned can be found in Fig. 1.

\subsection{July/August 2005}

A considerable flood affected the German part of the Danube catchment in August 2005. Cyclone Norbert closely followed the track of a $\mathrm{Vb}$ weather system and induced the advection of moist air from sub-tropical regions to Switzerland, northern Italy, Austria and southern Germany. The encounter with cold air masses and an orographic uplift at the northern face of the Alps led to prolonged rainfall with notably high amounts within 12 to $24 \mathrm{~h}$ (e.g. $216 \mathrm{~mm}$ in $24 \mathrm{~h}$ on $22 \mathrm{Au}-$ gust 2005 at Balderschwang; LfU, 2007). As a result, the alpine foothills were affected by flash floods characterized by a rapid increase in discharges and water levels. Inundations occurred both along the river Danube and its southern tributaries. Return periods of maximum discharges were classified as less than 1 in 100 years at the Iller, Schmutter, Amper, Inn and Isar rivers and as 1 in 20-50 years at the rivers Lech, Loisach and Mangfall. At the Danube river, highest return periods occurred at Ingolstadt and Kelheim in the range of 1 in 20-50 years (LfU, 2007). Flood protection measures as well as operation of dams and retention areas effectively reduced the flood impact. The total economic damage was estimated at about EUR 175 million in Germany (Kron, 2009). Damage to infrastructure amounted to EUR 50 million, damage to private households and to the commercial sector amounted to about EUR 70 million (LfU, 2006). 


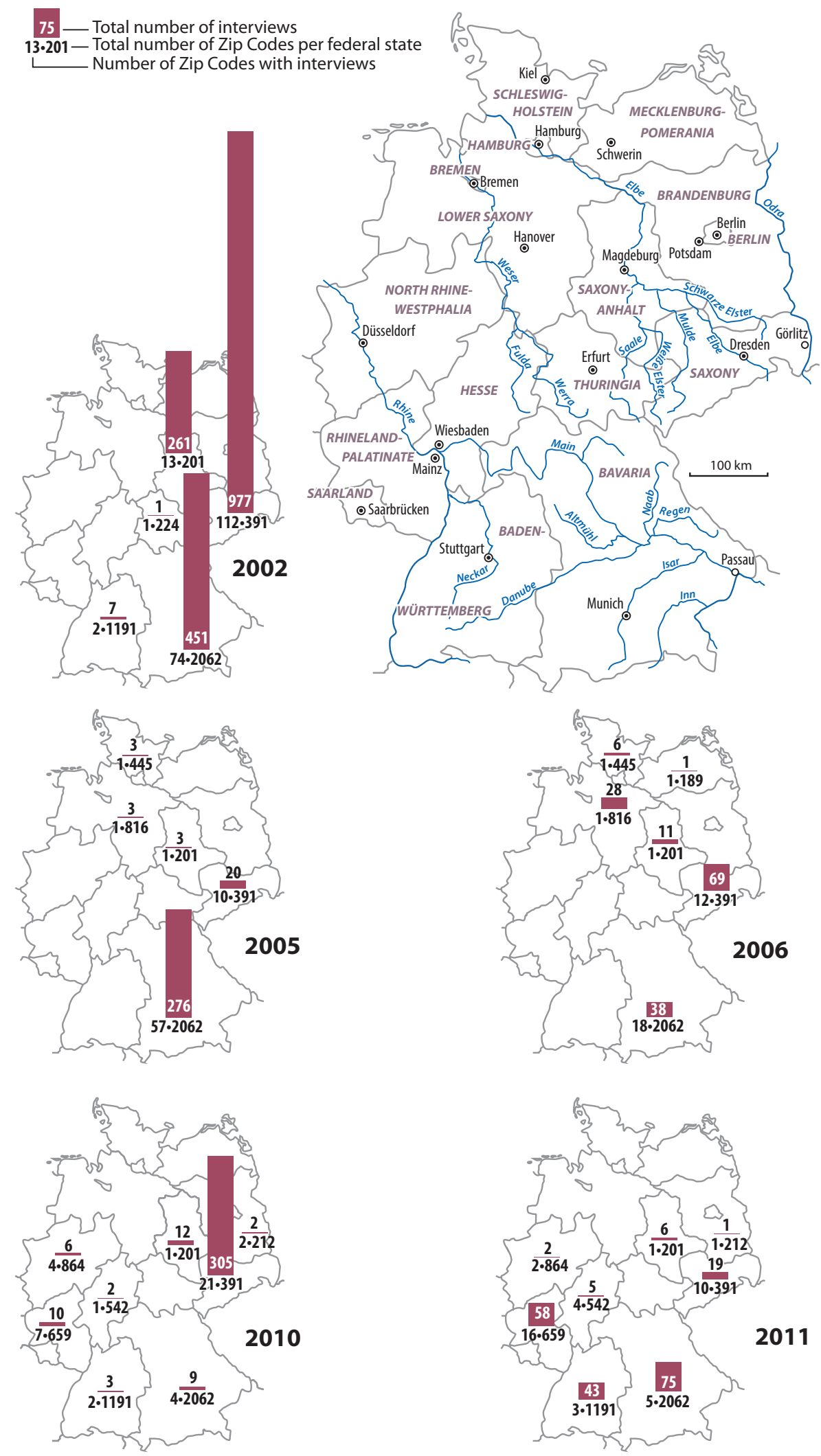

Figure 1. Federal states in which interviews of the respective subsamples were conducted. 
Table 2. Chronological overview of flood events and surveys.

\begin{tabular}{lcccc}
\hline Flood event & Subsample & $n$ & Period of interviews & $\begin{array}{c}\text { Time lag between flood event } \\
\text { and interviews [months] }\end{array}$ \\
\hline August 2002 & reference subset & 1697 & 8 April-10 June 2003 & $8-10$ \\
August 2005 & study subset & 305 & 20 November-21 December 2006 & $15-16$ \\
April 2006 & study subset & 156 & & $7-8$ \\
August 2010 & study subset & 349 & 16 February-20 March 2012 & $18-19$ \\
January 2011 & study subset & 209 & & $13-14$ \\
\hline
\end{tabular}

\subsection{March/April 2006}

The river flood in spring 2006 mainly occurred in the Elbe catchment. Due to exceptionally heavy snowfall during the winter of 2005/2006, the amount of water stored as snow was about 2.4 billion $\mathrm{m}^{3}$ at the beginning of 2006 in the upper Elbe catchment (Korndörfer et al., 2006). At the end of March, temperatures rose rapidly from 5 to $15^{\circ} \mathrm{C}$, leading to a complete snowmelt within one week, even in the upper areas of the middle hills (BfG, 2006). Additionally, heavy rainfall occurred in the whole upper catchment area of the river Elbe, e.g. upstream of the Dresden gauge, due to several westerly cyclones. The water levels in the Elbe catchment increased significantly on 26 March 2006 and relatively long-lasting plateau-like flood waves developed (IKSE, 2007). On 4 April 2006, peak flows were reached at the Schöna and Dresden gauges and on 5 April at the Torgau and Wittenberg gauges. Further downstream, peak flows were reached on 9 April at the Hitzacker, Neu Darchau and Geesthacht gauges. Water levels decreased slowly; only after 4 May 2006 had all water levels along the Elbe river dropped below the flood warning levels at the warning gauges (IKSE, 2007).

At the Dresden gauge, the flood discharge in 2006 $\left(2923 \mathrm{~m}^{3} \mathrm{~s}^{-1}\right)$ was the second-highest discharge since 1940 after the discharge in August $2002\left(4580 \mathrm{~m}^{3} \mathrm{~s}^{-1}\right)$, although its return period was estimated at only about 15 years (Kreibich and Thieken, 2009). Since no levee breaches occurred in the upper and middle reaches of the Elbe river, and since the retention areas at the Havel confluence were not activated, the flood situation downstream of the Havel confluence was comparable to or even worse than that in August 2002. For instance, at the Neu Darchau gauge, the flood discharge of $3600 \mathrm{~m}^{3} \mathrm{~s}^{-1}$ in 2006 was the second highest in 100 years and exceeded the 2002 flood discharge of $3400 \mathrm{~m}^{3} \mathrm{~s}^{-1}$ (BfG, 2006). Accordingly, resulting flood damage in Dresden was minor and thus significantly lower than in 2002 (Kreibich and Thieken, 2009). In contrast, the city of Hitzacker in Lower Saxony was heavily affected in 2006, and flooding of the whole city centre was more severe than in 2002 (IKSE, 2007). The total resulting damage in Germany was estimated to be EUR 120 million (Kron and Ellenrieder, 2008).

\subsection{August 2010}

Three heavy rainfall events in August and September 2010, of which the first one on 6/7 August was the most intense, resulted in extreme floods in the Oder and Elbe catchments (Walther et al., 2013). The heavy rainfall resulted from cyclone Viola, a $\mathrm{Vb}$ weather system, particularly in the Iser and Lusatian Mountains where maximal hourly rainfall amounted to $60 \mathrm{~mm}$ on the morning of 7 August (Jelonek et al., 2010). On 15/16 August, a cold front of a depression area moved in a northerly direction, resulting again in heavy rainfall in the southeastern part of Saxony in Germany. At the end of September, the low-pressure system Lya, a Genoa cyclone type $\mathrm{Vb}$ weather system, created a rain band with heavy precipitation stretching over Austria, the Czech Republic and Germany up to the Baltic Sea.

At the river Lusatian Neisse, as well as at the tributaries of the upper Elbe (e.g. Kirnitzsch river), the highest peaks occurred during the first flood wave at the beginning of August, with maximum discharges classified as 500-year flood events (Walther et al., 2013). The flood situation was aggravated significantly due to the breach of the Niedow Dam at the Witka river, which is a tributary of the Lusatian Neisse river, on 7 August (Jelonek et al., 2010). In the upper parts of the Schwarze Elster and Spree catchments, the highest peaks occurred at the beginning of August with return intervals of up to 500 years at the Spree and up to 200 years at the Schwarze Elster. At their lower reaches, the highest peaks occurred at the end of September with return intervals of 50 to 100 years (Walther et al., 2013). Particularly great damage occurred in the upper reaches of the Lusatian Neisse and Spree, as well as at the Mandau river. A total damage of EUR 839 million was reported to the EU Solidarity Fund in 2010 (EC, 2014).

\subsection{January 2011}

Processes leading to flooding in January 2011 were comparable with the flood in 2006, but affected a considerably larger area of Germany. Due to the cold winter with massive snowfall, a lot of water was stored as snow in many parts of Germany. An inflow of warm air in combination with heavy rainfall led to a large snow melt and an initial increase in river discharges between 5 and 6 January 2011. In the fol- 
lowing, i.e. between 12 and 14 January 2011, large-scale, intense rainfall fell on already saturated soils, which led to a second flood wave with water levels above the flood warning levels at many gauges (Axer et al., 2012). Nearly all large catchments in Germany were affected, e.g. the catchments of the Rhine, Danube, Weser and Elbe (Axer et al., 2012). Particularly high discharges occurred at the rivers Main and Saale and in the upstream part of the Weser catchment. In Saxony-Anhalt at the rivers Elbe, Saale, Havel, Schwarze Elster, Weiße Elster, Wipper and Bode, water levels increased to alarm level 4 around 15 January (LHW, 2011). Flooding occurred and resulted in damage in the catchments of the Rhine, Danube, Weser and Elbe. The total damage was estimated to be more than EUR 100 million in Germany (Axer et al., 2012).

\section{Data and methods}

\subsection{Procedure for sampling flood-affected private households}

The data set contains information collected by computeraided telephone interviews of private households that suffered from property damage due to flooding in 2002, 2005, 2006, 2010 or 2011 (Fig. 1). In the following, the flood events in 2005, 2006, 2010 and 2011 are referred to as study subsets, and the 2002 event as a reference subset (Table 2). Since the compilation of the reference data set was already described by Thieken et al. $(2005,2007)$, only the collection of the study subsets is described.

On the basis of flood reports or press releases, as well as with the help of flood masks derived from satellite data (DLR, Centre for Satellite-Based Crisis Information, www.zki.dlr.de), lists of inundated streets were compiled for each flood event. These lists served as a basis from which to select telephone numbers of all potentially affected residents/households from the public telephone directory. Computer-aided telephone interviews were undertaken with the VOXCO software package (www.voxco.com) by the Explorare market research institute (www.explorare. de), once in November/December 2006 and again in February/March 2012 (Table 2). At the beginning of the interview, we asked to interview the person in the household with the best knowledge about the flood event.

Difficulties conducting a sufficient number of interviews resulted from the fact that approximately $40 \%$ of households called had not been affected by flooding. In this regard, more precise information on the maximum flood extent would help to improve the lists of affected streets that are the basis for the sampling process. In total, 461 interviews were conducted in 2006, of which 305 interviewed households had been affected in 2005 and 156 in 2006. The second campaign resulted in 658 interviews, with 349 households affected in 2010 and 209 households affected in 2011 (Table 2). The
Table 3. Numbers and percentages of interviews with respect to the affected river catchment.

\begin{tabular}{|c|c|c|c|c|c|c|c|c|c|c|}
\hline \multirow{3}{*}{ Catchment } & \multicolumn{2}{|c|}{$\begin{array}{c}\text { Reference } \\
\text { subset }\end{array}$} & \multicolumn{8}{|c|}{ Study subsets } \\
\hline & \multicolumn{2}{|c|}{2002} & \multicolumn{2}{|c|}{2005} & \multicolumn{2}{|c|}{2006} & \multicolumn{2}{|c|}{2010} & \multicolumn{2}{|c|}{2011} \\
\hline & & $\%$ & $\mathrm{n}$ & $\%$ & $\mathrm{n}$ & $\%$ & $\mathrm{n}$ & $\%$ & $\mathrm{n}$ & $\%$ \\
\hline Danube & 449 & 26 & 276 & 90 & 41 & 26 & & & & \\
\hline Elbe & 1248 & 74 & 29 & 10 & 115 & 74 & 162 & 46 & 21 & 10 \\
\hline Oder & & & & & & & 157 & 45 & 5 & 2 \\
\hline Rhine & & & & & & & 30 & 9 & 183 & 88 \\
\hline Total & 1697 & & 305 & & 156 & & 349 & & 209 & \\
\hline
\end{tabular}

remaining 100 interviews were carried out with households affected by torrential rains in the city of Osnabrück in $\mathrm{Au}-$ gust 2010; however, these data are not included in the current analyses. The respective numbers and proportions of interviews referring to the affected river catchments are listed in Table 3.

\subsection{Contents of the questionnaire and data processing}

For the two campaigns, the questionnaire presented in Thieken et al. (2005, 2007) was slightly adapted. Altogether, the questionnaires contained about 180 questions addressing the following topics: flood impact, contamination of the flood water, flood warning, emergency measures, evacuation, clean-up, characteristics of and damage to household contents and buildings, recovery of the affected household, precautionary measures, flood experience, and socio-economic variables. For our analyses, we selected only those variables presented in Thieken et al. (2007) for the flood event in 2002 in order to enable a consistent comparison of the different flood events (Table 4). These variables differed significantly in the regions that were investigated by Thieken et al. (2007) and are hence assumed to provide reasonable information for the comparison of different flood events.

In a number of questions, people were asked to rank qualitative or descriptive variables on a scale from 1 to 6 , where " 1 " described the best case and " 6 " the worst case. The meaning of the end points of the scales was given to the interviewee (see Table 4). The intermediate rankings could be used to graduate the evaluation.

To analyse the amounts of financial loss, some assumptions had to be made. In the survey, some respondents did not put a precise figure on their financial damage, but indicated, for example, that they had "hardly suffered damage" or "only electricity costs for operating the pump". In order to quantify these kinds of damages, a flat-rate loss of EUR 250 had been attributed to such cases. This amount was determined by the authors and represents approximately the average deductible for natural hazard insurances in Germany. However, for the calculation of the average and median losses, the cases with an added flat-rate value were not taken into account. 
Table 4. Items of the survey that were used in this paper.

\begin{tabular}{|c|c|}
\hline Item & Units and labels \\
\hline \multicolumn{2}{|l|}{ Socio-economic variables } \\
\hline Age of the interviewee & Number of years \\
\hline Education & Type of degree \\
\hline Household size & Number of people \\
\hline Monthly net income of the household & Euro \\
\hline Living area per person & $\mathrm{m}^{2}$ \\
\hline Homeowners & tenant/homeowner/owner of a flat \\
\hline \multicolumn{2}{|l|}{ Flood experience before the flood event } \\
\hline Previously experienced floods & Number of events \\
\hline Time period since the last flood event & Number of years \\
\hline $\begin{array}{l}\text { Knowledge about the flood hazard of the } \\
\text { residence/plot (only questioned when no } \\
\text { previous flood had been experienced) }\end{array}$ & 0: no knowledge, 1: knowledge of flood hazard \\
\hline \multicolumn{2}{|c|}{ Preparedness (before/after the flood) and risk awareness } \\
\hline Informational precaution & Type of measures and time of performance \\
\hline Flood insurance & $0:$ no insurance, 1 : insurance, and time of contract conclusion \\
\hline Flood-proofing measures and retrofitting & Type of measures and time of implementation \\
\hline \multicolumn{2}{|l|}{ Characteristics of the inundation } \\
\hline Water level & $\mathrm{cm}$ above top ground surface \\
\hline Flood duration & Hours \\
\hline Contamination of the flood water & $\begin{array}{l}0: \text { no contamination, } 1 \text { : sewage, } 2 \text { : chemicals (and sewage), } \\
\text { 3: oil (and chemicals or sewage) }\end{array}$ \\
\hline \multicolumn{2}{|c|}{ Warning and response before/during the flood event } \\
\hline Lead time & Hours \\
\hline Perceived knowledge about self-protection & Rank from 1 (I knew exactly what to do) to 6 (I did not know what to do) \\
\hline Emergency measures & $\begin{array}{l}\text { Type of measure performed and perceived effectiveness of each measure } \\
\text { evaluated on a scale from } 1 \text { (very effective) to } 6 \text { (totally ineffective) }\end{array}$ \\
\hline \multicolumn{2}{|l|}{ Adverse effects of the flood events } \\
\hline Damage to the building & Euro \\
\hline Damage to household contents & Euro \\
\hline \multicolumn{2}{|l|}{ Recovery } \\
\hline $\begin{array}{l}\text { Perceived status of restoration of the } \\
\text { building/replacement of household } \\
\text { contents at the time of the interview }\end{array}$ & $\begin{array}{l}\text { Rank from } 1 \text { (buildings/household contents are already completely restored/replaced) } \\
\text { to } 6 \text { (there is still considerable damage to the building/to household contents) }\end{array}$ \\
\hline
\end{tabular}

Regarding the recovery analyses, it should be noted that due to the different time lags between the surveys and the respective flood events (see Table 2) the results could not easily be compared with each other. To ensure comparability, only data of those flood events which were collected after a similar time lag could be compared. This applied to the years 2002 and 2006, where respondents were interviewed 7 to 9 months after the flood event; and also to 2005, 2010 and 2011, where the corresponding time lags were between 13 and 19 months (compare Table 2).

\section{Results and discussion}

\subsection{General characteristics of the four study subsets}

The characteristics of the four study subsets and the reference data set, statistics of the flood impact, socio-economic variables and flooding experienced prior to the events under study are summarized in Table 5.

In all four study subsets, respondents were aged between 50 and 60 years on average, though interviewees in 2010 and 2011 were slightly older. These figures are considerably 
Table 5. Description of the different flood events with respect to socio-economic variables, previously experienced floods and flood impact (figures do not refer to all interviews, but to the respective number of valid responses).

\begin{tabular}{|c|c|c|c|c|c|c|}
\hline Flood event & 2002 & 2005 & 2006 & 2010 & 2011 & Germany \\
\hline \multicolumn{7}{|l|}{ Socio-economic variables } \\
\hline Mean age of the interviewees [years] & 52 & 52 & 55 & 57 & 57 & $\begin{array}{c}\text { male: } 43, \\
\text { female: } 46(2012)^{1}\end{array}$ \\
\hline $\begin{array}{l}\text { People with high school graduation/university degree } \\
\text { (German: Abitur/Fachabitur/Hochschul-/ } \\
\text { Fachhochschulabschluss) [\%] }\end{array}$ & 31 & 38 & 39 & 28 & 33 & unknown \\
\hline Mean household size [number of people] & 3 & 3 & 3 & 3 & 3 & $2(2010)^{2}$ \\
\hline Households with a monthly net income < EUR 1500 [\%] & 30 & 19 & 28 & 26 & 14 & $26(2008)^{3}$ \\
\hline Mean living area per person $\left[\mathrm{m}^{2}\right]$ & 48 & 49 & 51 & 46 & 63 & $45(2010)^{4}$ \\
\hline Homeowners $[\%]$ & 76 & 77 & 83 & 85 & 89 & $46(2010)^{4}$ \\
\hline \multicolumn{7}{|l|}{ Flood experience before the respective event } \\
\hline People who experienced at least one previous flood [\%] & 22 & 55 & 83 & 52 & 78 & \\
\hline thereof: People who experienced a flood in the last ten years [\%] & 58 & 74 & 89 & 58 & 75 & \\
\hline People who had not experienced at least one previous flood [\%] & 78 & 42 & 13 & 47 & 22 & \\
\hline $\begin{array}{l}\text { thereof: People with knowledge about the } \\
\text { flood hazard of their property [\%] }\end{array}$ & 31 & 52 & 52 & 41 & 69 & \\
\hline \multicolumn{7}{|l|}{ Characteristics of the flood impact } \\
\hline Mean flood duration $[\mathrm{h}]$ & 143 & 52 & 146 & 67 & 104 & \\
\hline Mean water level above top ground surface $[\mathrm{cm}]$ & 64 & -19 & 19 & 58 & -20 & \\
\hline Interviews that reported oil or petrol contamination [\%] & 38 & 14 & 14 & 16 & 7 & \\
\hline
\end{tabular}

${ }^{1} \mathrm{BiB}, 2014 \mathrm{a} ;{ }^{2} \mathrm{BiB}, 2014 \mathrm{~b} ;{ }^{3}$ Kott and Behrends, $2011 ;{ }^{4}$ DESTATIS, 2013.

higher than the average age of the German male or female population (BiB, 2014a). This may hint at a methodological problem that has emerged recently. Only households in the central telephone register could be included in the sample. Due to the increasing use of mobile phones, elderly people and homeowners with landlines may tend to be overrepresented in the sample. Furthermore, in 2005 or 2006 more people had a high school or university degree than in 2010 or 2011. Yet in 2011, the share of households with a net income of less than EUR 1500 was the smallest, and more people owned the house or flat in which they lived, which was also much larger in terms of mean living area per person than in the other subsets. Mean household size was about the same in all years, only slightly bigger in 2005 . The socio-economic results of the reference subset collected after 2002 in general were in the same range as the results of the other study subsets.

Concerning flooding experienced before the respective event, considerable differences between individual study subsets could be found, which was particularly evident for the study subset 2010 . The percentage of respondents who had experienced at least one previous flood was much higher in 2006 and 2011 at 83 and $78 \%$, respectively, than in the years 2005 and 2010 at 55 and $52 \%$, respectively. In 2005, 2006 and 2011, between 74 and $89 \%$ of these flood-affected interviewees stated that they had experienced flooding within the last ten years. In contrast, this was only the case for $58 \%$ of flood-affected respondents in 2010.

Furthermore, it is striking that among those respondents who had never experienced a flood a large group of people nevertheless knew about their risk. In the study subsets of 2005, 2006 and 2010, this proportion ranged between 41 and $52 \%$; in 2011 it was even $69 \%$.

Looking at the reference subset 2002, previous flood experience was considerably lower than in subsequent flood years. In 2002 , only $22 \%$ of respondents had experienced one flood before and $58 \%$ of those people experienced a flood within the last ten years. The share of people who had not experienced a flood but at least knew they were at risk amounted to $31 \%$. Overall, a larger part of respondents of the study subsets had a lot more experience with flooding and also knew to a greater extent that they were at risk than respondents in the reference subset 2002. However, the results from 2010 stand out from the other flood years, indicating generally lower risk awareness.

The flood impact differed between all four events. As outlined in Sect. 2, the flood events in 2005 and 2010 had both been typical summer floods due to local heavy rainfall events with fast reacting run-off processes and can therefore be classified as rapid-onset floods, whereas floods in 2006 and 2011 
occurred in the Spring/Winter at a larger scale with slower run-off processes and can be classified as river floods. Hence, the mean flood duration in the study subsets 2005 and 2010 was considerably shorter than in the study subsets 2006 or 2011. The impacts of the flood with respect to mean water level and contamination were most severe in the study subset 2010, which also reflects the severity of the flood event as described in Sect. 2.3. In comparison, during the 2002 summer flood, both flood characteristics occurred: river floods occurred along the main rivers and rapid-onset floods in the headwaters (see Ulbrich et al., 2003). The resulting mean flood duration was comparable to the study subset of 2006. However, the mean water level and contamination were still much worse than in any of the other study subsets (Table 5).

\subsection{Preparedness before the flood events}

Private preparedness before a flood event is an important component of flood risk management, as it can have a significant effect on flood loss mitigation. It includes three types of precautionary measures: (1) information and behavioural precautions, e.g. collecting information about the flood hazard and protection, as well as participation in networks; (2) flood-proofing and retrofitting measures, e.g. adapting the building structure or usage of the premises and furniture, reconstructing the heating system or purchasing water barriers; and, (3) risk precautions, e.g. contracting a flood insurance (LAWA, 1995; ICPR, 2002; DKKV, 2003; BMVBS, 2008; Kreibich et al., 2005, 2011).

With respect to precautionary behaviour before the respective flood event of the study subsets, more than $90 \%$ of all respondents performed at least one precautionary measure; in contrast, only $7 \%$ did not carry out any measures at all. Generally, interviewees mostly gathered information about the flood hazard and how to protect themselves (58\%), as well as participated in networks (43\%) (Fig. 2). Although collection of information is an important first step, these measures alone do not lead to damage mitigation. This is only possible if the knowledge is further translated into real action. Hence, damage reduction is achieved exclusively through precautionary measures like flood-proofing and building retrofitting or emergency measures (see ICPR, 2002; Kreibich et al., 2005). With regard to flood-proofing and building retrofitting, adaptation of interior equipment (43\%) and building use (39\%) were more often performed by the respondents in the study subsets than any other precautionary measure, e.g. replacement of oil heating, purchasing water barriers or sealing the basement.

When comparing the individual study subsets, however, clear differences in the performance of measures can be identified. The highest percentages of households that undertook actions before the flood were most frequently recorded in 2011. Acquisition of information, adaptation of building use and furnishing, as well as purchasing water pumps and avoiding environmental contamination were carried out by more than $60 \%$ of respondents. All other measures, however, were performed by less than $40 \%$ of households interviewed. Second-best prepared were the people affected in 2006. Before 2005, most of these measures were performed the least often. Only the oil heating was most frequently replaced. The reason for this might be that in 2005, especially the Danube catchment was affected by the flood. These people had already suffered severe flood damage in 1999 due to oil contamination and had subsequently retrofitted their heating system (Müller, 2000). Moreover, Bavarian authorities introduced a one-time safety inspection of large oil tanks in flood areas (LfU, 2014). In addition, in 2005 more buildings were heated with oil $(45 \%)$ than in the other three study subsets (2006: $23 \%$, 2010: $24 \%, 2011: 35 \%$ ).

It is also striking that insurance against damage due to flood hazards was more often contracted by people interviewed in $2010(57 \%)$ and $2006(39 \%)$ than by people interviewed in $2005(27 \%)$ or $2011(25 \%)$. This fact must be seen in the context of Germany's insurance history. In the former states of the German Democratic Republic, which were primarily affected by floods in 2010 and 2006, flood insurance was included in the household contents policy. Today, many local people still have similar contracts. In the West German states, excluding Baden-Württemberg, flood insurance is less common and was introduced only in 1994 as a voluntary supplementary contract to the building insurance (Thieken et al., 2006; GDV, 2013).

Overall, the state of private precautions was clearly higher before recent events than before the reference event in 2002, where most respondents relied on flood insurance to counterbalance financial losses $(41 \%)$ and gathered information about precautions (30\%). Flood-proofing and retrofitting measures were carried out by less than $15 \%$ of the respondents.

Furthermore, people were asked how they perceived the general effectiveness of private precautionary measures. Answers were evaluated on a scale ranging from 1 (is private precautionary measures can reduce flood damage very effectively) to 6 (is private precautionary measures are totally ineffective for flood damage reduction). The results of the study subsets show that the perceived effectiveness of measures rose almost steadily from year to year (Fig. 3). In 2005, $47 \%$ of respondents rated the effectiveness as 1 or 2 . In 2006 and 2010, the respective value was $52 \%$, and even $67 \%$ in 2011 . By contrast, flood-affected people in the reference subset 2002 perceived the effectiveness as generally lower. Merely $39 \%$ of the respondents chose a score of 1 or 2 (Fig. 3).

Altogether, it can be concluded that today people are much better prepared in case of flooding than they were in 2002 , and confidence in the effectiveness of precautionary measures has steadily increased. However, on the basis of the four study subsets, no constant improvement of private precaution could be identified over the course of time. In fact, the level of precaution before the flood events in 2011 and 2006 was strikingly higher compared to that before 2005 


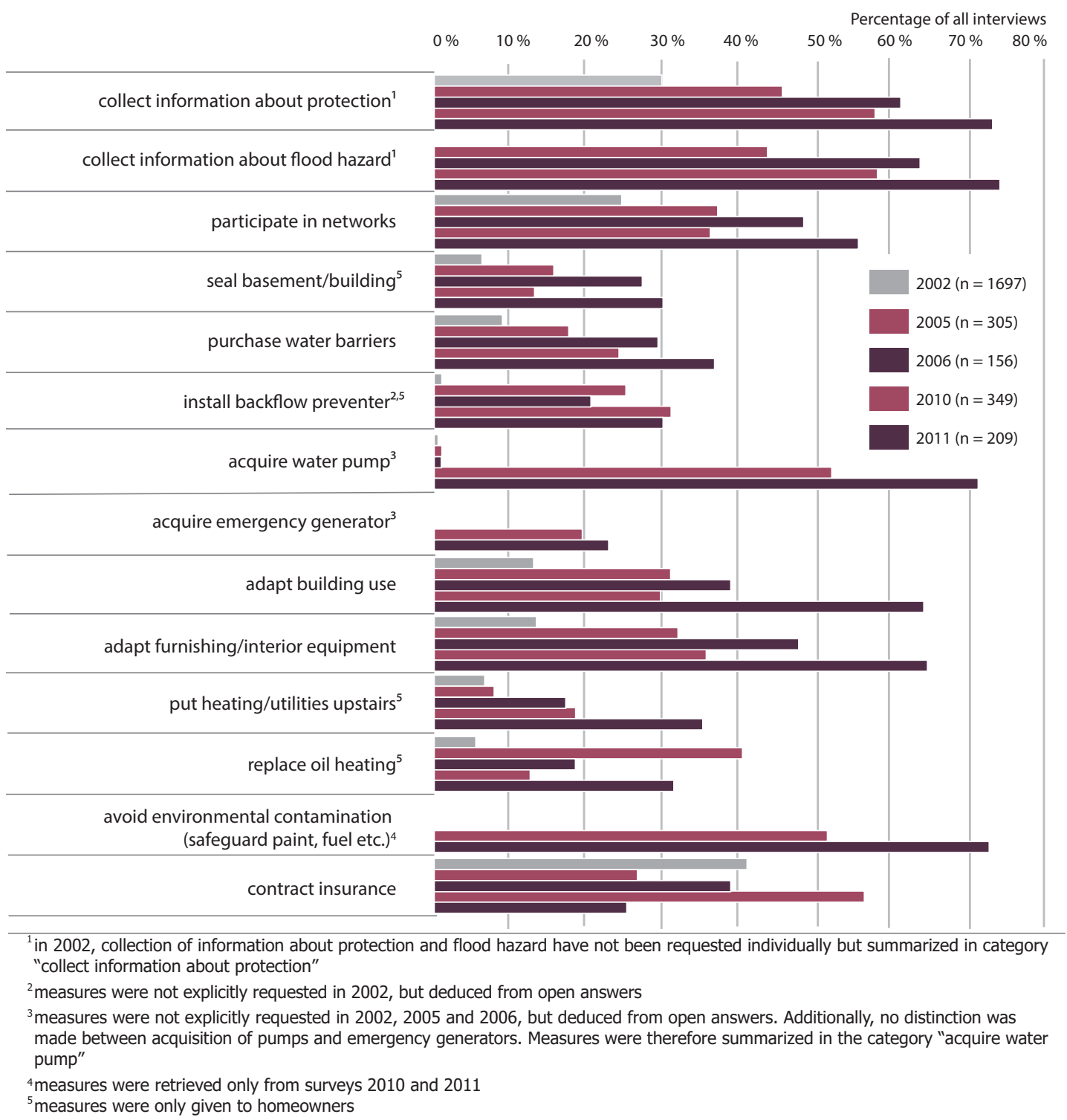

Figure 2. Precautionary measures performed by private households before the respective flood event.

or 2010. One explanation for these differences between the four study subsets might be the difference in personal flood experiences. The highest percentages of precautionary measures performed before 2011 and 2006 are associated with the greatest previous flood experience (see also Table 5).

In their review, Bubeck et al. (2012a) list several studies that also found a (weak) positive correlation between the two factors of personal flood experience and performance of precautionary measures (Grothmann and Reusswig, 2006; Siegrist and Gutscher, 2006; Lindell and Hwang, 2008; Kreibich et al., 2011). However, there are also studies in which this relationship was not significantly confirmed (Takao et al., 2004; Thieken et al., 2007). Besides the frequency of flood experience, the time lag from the last experienced flood event is also assumed to be a relevant fac-

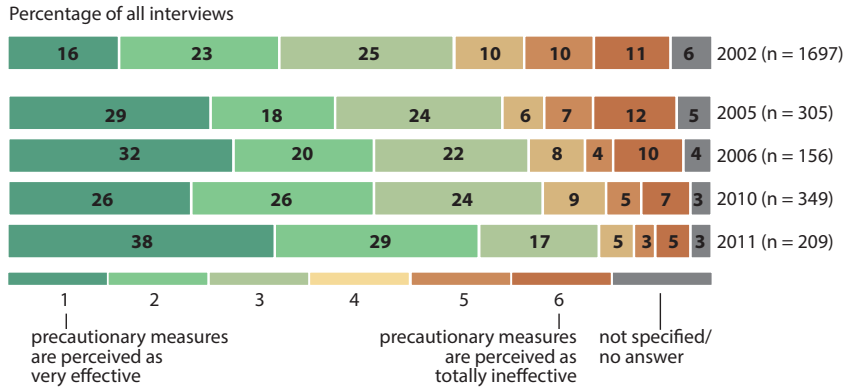

Figure 3. Perceived effectiveness of private precautionary measures. 
tor for mitigation behaviour, as it is linked to people's flood risk awareness. Unless no information campaigns are conducted or precautionary measures implemented in the aftermath of an event, risk awareness is assumed to constantly diminish within seven years and to only remain for a longer period after catastrophic disasters (ICPR, 2002). As a result, people's motivation to invest in precautionary measures decreases over time. Before the flood event in 2010, for example, many respondents in the Oder-Neisse catchment had only rarely been affected by a flood, which also dated back several years. This applied especially to people who were affected by the severe flooding event in 2002. In light of the above, the lower percentages of precautionary measures performed before 2010 or 2002 might be explained. In this context, however, it is noteworthy that by far the most respondents affected by the flood in 2011 knew that they lived in a flood-prone area, although they did not experience a previous flood. This reflects a profound awareness of the flood risk in this area and might be a reason for their outstanding preparedness before 2011. Nevertheless, it cannot always be assumed that flood experience and increased risk awareness will lead to an implementation of precautionary measures. For example, Wachinger et al. (2013) demonstrated that individuals who experienced flooding but did not suffer damages do not necessarily take (more) preparedness actions in the future. In fact, these people may assume that they will not be affected by future flood events ("risk perception paradox"). Furthermore, our results indicate that the knowledge of one's own potential flood risk and the information about protection did not necessarily result in technical or structural building retrofitting or flood-proofing measures. Even before the flood event in 2011, these measures were carried out to a lesser extent. This fact underlines that the benefits and cost savings of these actions still have to be communicated in a better way. However, it has to be taken into account that some of the flood-proofing or building retrofitting measures can only be undertaken by homeowners and not by tenants. Therefore, only homeowners were asked to evaluate all measures (see Fig. 2).

\subsection{Warning and response}

Damage mitigation not only depends on long-term preparedness, but also on people's awareness in the case of an approaching event and their reaction.

\subsubsection{Flood warning and lead time}

To respond to a flood, people need to be made aware of the risk through warnings and need to be alerted. Early warning systems and crisis communication play a decisive role in this context. However, people's response to warnings is above all dependent on the warning lead time, which in turn is strongly dependent on the catchment size and shape as well as on flood characteristics. Longer lead times of several days can be provided in the middle to lower reaches of large river catchments due to the temporally extended flow of the flood wave (river flood). In contrast, lead times for small mountain rivers in the upper basins are more to the order of a few hours to one day because of fast-reacting run-off processes (medium to rapid-onset floods) (Bürgi, 2002; Younis et al., 2008; Golding, 2009). Timely and reliable rainfall forecasts are of utmost importance in these cases. Accordingly, spatial information dissemination and warning quality can vary greatly due to these characteristics.

This linkage is also reflected in the flood warning results obtained in this study. As described in Sect. 2, catchment and flood characteristics of the four flood events differed, with the result that the 2005 and 2010 flood events were classified as rapid-onset floods and the 2006 and 2011 events as river floods. Hence, there were considerable differences with respect to the average lead times. In 2010 and 2005, mean lead times of 11 and $16 \mathrm{~h}$ were reported, respectively, whereas respondents in 2011 and 2006 had on average at least 23 and $40 \mathrm{~h}$ time, respectively, to prepare for the flood. The mean lead time in the reference subset 2002 was approximately in the 2006 range (Table 6). At that time, however, there was also a spatial heterogeneity with regard to the flood processes and warning (see Thieken et al., 2007).

The longer lead times had a positive effect on the dissemination of flood information in the study subsets. Therefore, the best dissemination of flood information was achieved in 2011 and 2006. Only 6\% (2011) and 12\% (2006) of the people did not receive a warning, in contrast to 2005 and 2010, where these values reached 27 and even $32 \%$, respectively (Table 6). Within the context of warning sources, warnings by authorities are very important as they are considered trustworthy. Most respondents received an official warning in 2011 (45\%); however, again due to lack of time, the lowest percentage of respondents received it in 2010 (33\%).

With respect to the percentage distribution of all warning sources, Thieken et al. (2007) found for the reference year 2002 that responses were already very heterogeneous within the spatial distribution of the 2002 flood event. When comparing the results of 2002 to the average percentage of all study subsets, it can be seen that the respective values do not exhibit any trend, but are rather different (Table 6). In view of that, the regional topography and flood characteristics appear to be the best determining factors for the warning sources.

\subsubsection{Warning content and reaction capabilities}

Receiving a timely flood warning is just one of the key preconditions to performing emergency measures. As mentioned above, it also depends on the quality of the warning content. The information content of flood warnings by authorities was therefore investigated in further detail. The results revealed that warnings were comprehensive in all investigated study subsets. The comparison of the individual subsets showed that in 2010 information about residential areas 
Table 6. Answers to the question: "How did you become aware of the danger of flooding?" given in percentage of all interviewed people per flood event (multiple answers possible) and average lead time per subsample.

\begin{tabular}{lrrrrrc}
\hline Flood event & 2002 & 2005 & 2006 & 2010 & 2011 & Total (2005-2011) \\
\hline Own observation [\%] & 33 & 29 & 29 & 41 & 57 & 39 \\
Flood warning by authorities [\%] & 41 & 33 & 34 & 23 & 45 & 32 \\
Severe weather warning by radio, TV etc. [\%] & $\mathrm{a}$ & 24 & 42 & 20 & 42 & 29 \\
Warning by neighbours, friends etc. [\%] & 13 & 12 & 17 & 16 & 16 & 15 \\
General reporting in nationwide news [\%] & 14 & 9 & 13 & 6 & 12 & 9 \\
Gauge information [\%] & $\mathrm{a}$ & $\mathrm{a}$ & $\mathrm{a}$ & 0 & 3 & $1^{\mathrm{b}}$ \\
Warning and evacuation at the same time [\%] & 1 & $\mathrm{a}$ & $\mathrm{a}$ & $\mathrm{a}$ & $\mathrm{a}$ & \\
Other warning sources (sms, public services) [\%] & 0 & 0 & 0 & 0 & 0 & 0 \\
No warning [\%] & 27 & 27 & 12 & 32 & 6 & 22 \\
No answer [\%] & 1 & 1 & 1 & 0 & 0 & 1 \\
\hline Number of valid interviews & 1697 & 305 & 156 & 349 & 209 & 1019 \\
\hline Average lead time [h] & 37 & 16 & 40 & 11 & 23 & 20 \\
Number of valid interviews & 1005 & 156 & 103 & 173 & 158 & 590 \\
\hline
\end{tabular}

${ }^{a}$ Data were not requested; ${ }^{b}$ total value results from calculations of years 2010 and 2011.

Table 7. Information content of official flood warnings (multiple answers possible).

\begin{tabular}{lrrrrrc}
\hline Flood event & 2002 & 2005 & 2006 & 2010 & 2011 & Total (2005-2011) \\
\hline Maximal water level [\%] & 33 & 39 & 60 & 36 & 68 & 50 \\
Residential areas at risk [\%] & 57 & 48 & 46 & 52 & 51 & 50 \\
Time to peak water level [\%] & 26 & 33 & 58 & 26 & 47 & 39 \\
Advice for damage reduction [\%] & 35 & 38 & 29 & 49 & 31 & 37 \\
Information about diversions, road blocks etc. [\%] & $*$ & 9 & 27 & 26 & 21 & 20 \\
Information about evacuation [\%] & 23 & 21 & 25 & 29 & 4 & 19 \\
Information about levee breaches [\%] & $*$ & 6 & 6 & 17 & 3 & 8 \\
Other useful information [\%] & 2 & 1 & 2 & 0 & 0 & 1 \\
$\quad$ snowmelt, emergency numbers [\%] & 10 & 10 & 15 & 6 & 4 & 9 \\
None of this information [\%] & 5 & 9 & 2 & 8 & 10 & 8 \\
Not specified/no answer [\%] & 647 & 97 & 52 & 77 & 90 & 316 \\
\hline Number of valid interviews & & & & & &
\end{tabular}

* Inter alia data were classified as "other useful information".

at risk (52\%), advice for damage reduction (49\%), evacuation $(29 \%)$ and levee breaches (17\%) were reported more often than in any other study subset (Table 7). Other warning content such as information on maximal water level (68\%), time to peak water level $(58 \%)$ or information about diversions or road blockings ( $27 \%$ ) were most often included in 2006 or 2011.

In summary, however, no clear information on content improvement can be derived from the study subsets compared to the reference year 2002. Again, it is assumed that the quality of warnings depends to a large extent on the flood characteristics, but also on the number of previously experienced floods, as authorities that disseminate warning information certainly improve with an increasing number of flood events. Furthermore, flood warnings are the responsibility of the in-

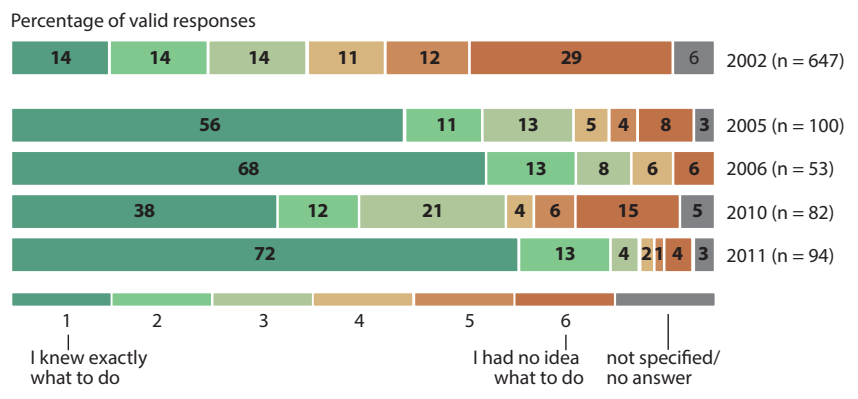

Figure 4. People's knowledge about how to protect themselves and their households against the flood. 


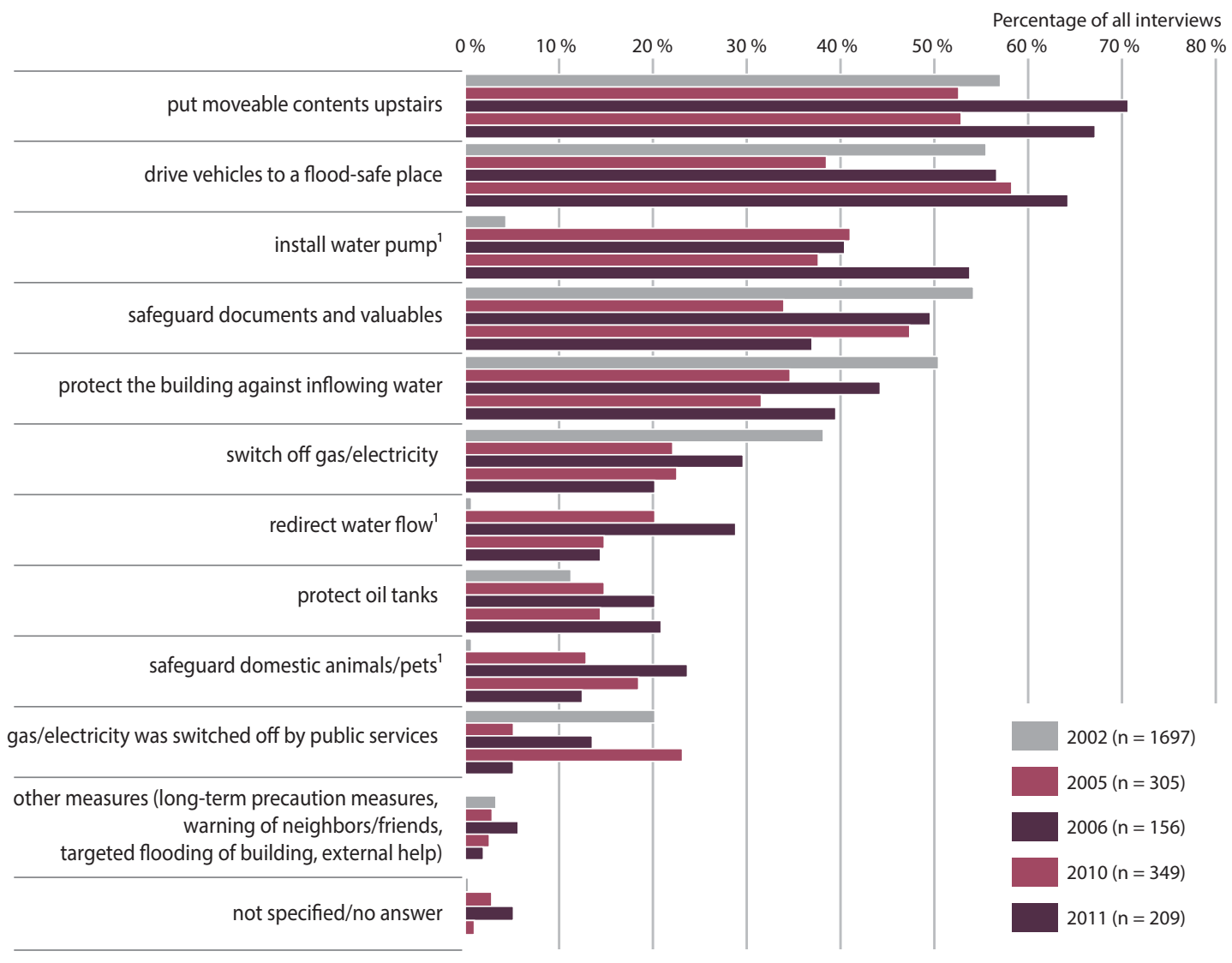

${ }^{1}$ these measures were not specifically requested in 2002 but deduced from open answers

Figure 5. Emergency measures performed (in descending order), as a percentage of all people interviewed per year (multiple answers possible).

dividual federal states, so that there might also be regional differences in the quality of warnings. Moreover, it has to be acknowledged that the number of valid answers was rather small (see Table 7).

Furthermore, respondents who received an official flood warning were asked to evaluate their knowledge in order to protect themselves and their households based on the warning received. On a scale from 1 (is I knew exactly what to do) to 6 (is I had no idea what to do), approximately $67 \%$ (2005), $81 \%$ (2006) and $85 \%$ (2011) of the study subset interviewees responded with a 1 or 2 (Fig. 4). Alone in 2010, this share was $50 \%$. However, the corresponding figure for the reference subset 2002 was even lower $(28 \%)$.

The data reveal that the awareness of emergency preparedness of flood-affected residents had considerably increased after 2002, also in areas that had not experienced flooding for a longer time, which holds for the subset of 2010 (compare Table 5 and Fig. 4). The question arises whether this knowledge could be used to mitigate damage. Therefore, the next sections deal with emergency measures and the resulting losses.

\subsubsection{Emergency measures}

In the case of an imminent flood hazard, emergency measures are predominantly performed to mitigate potential loss and damage (Molinari et al., 2013). On average, more than $50 \%$ of all respondents in the four study subsets performed emergency measures, such as putting moveable contents upstairs and driving vehicles to a flood-safe place. Further measures carried out frequently aimed at protecting the building from water entering (e.g. by installing a water pump or mobile barriers) or safeguarding important documents and valuables. However, data on individual study subsets showed that the highest percentages were mostly found for the study subsets 2006 or 2011 (Fig. 5). Gas/electricity was most frequently switched off centrally by public services in 2010 .

In the reference subset 2002, the use of water pumps, redirection of water flow and the safeguarding of domestic animals seemed to be of only little importance as emergency measures. However, this is related to the fact that these items were not specifically requested in 2002, but deduced from open answers. In fact, more people safeguarded documents and valuables, switched off gas or electricity, and protected 


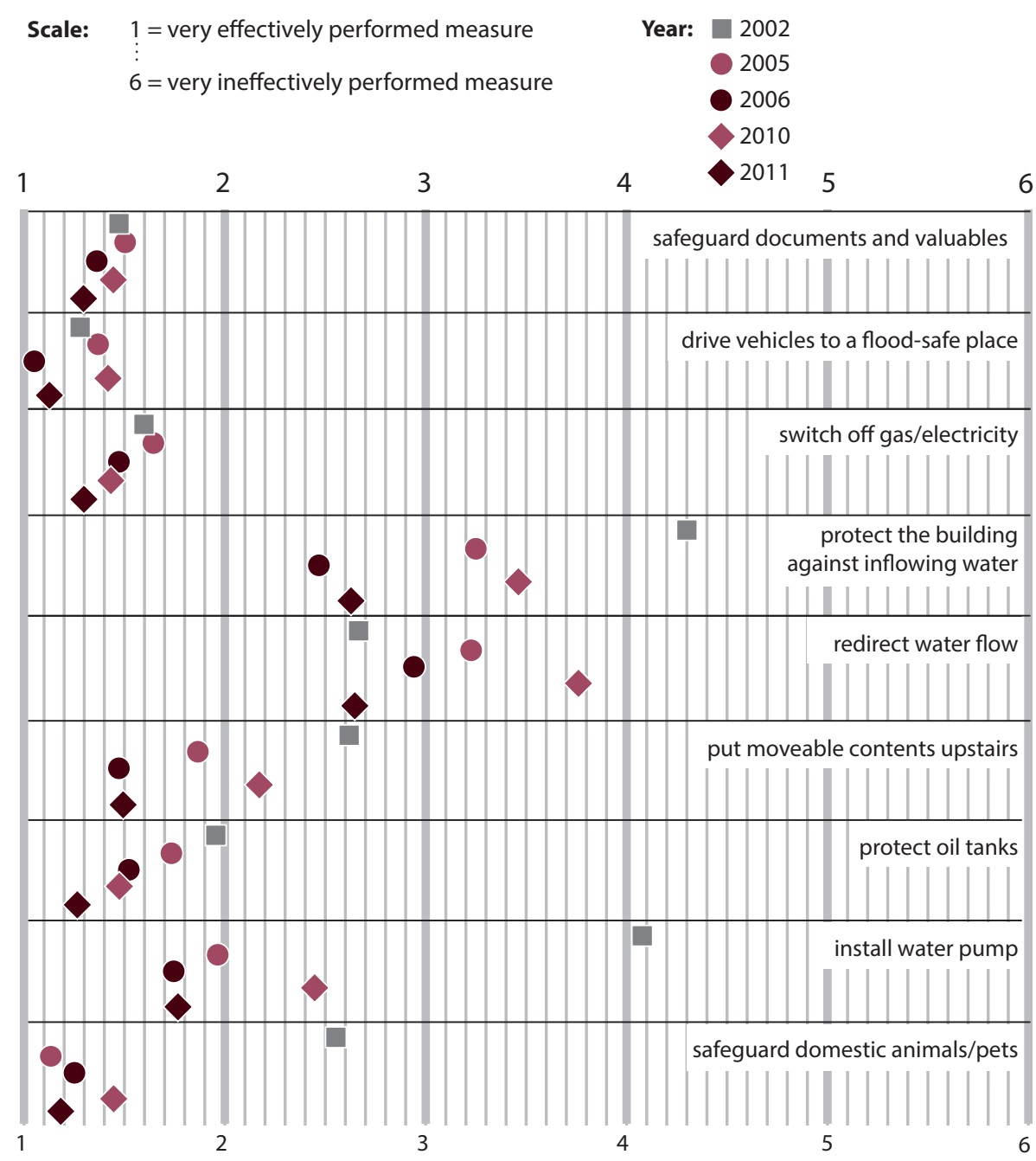

Figure 6. Average effectiveness of emergency measures as evaluated by the people interviewed on a scale from 1 (if measure was very effective) to 6 (if measure was very ineffective).

the building against inflowing water than people in any other study subset investigated. An explanation for this could be that the lower (long-term) preparedness level in 2002 (see Sect. 4.2.) had to be compensated by an increased performance of emergency measures.

Successful damage reduction not only depends on the general performance of emergency measures, but also on their effectiveness. Therefore, emergency measures performed were assessed by respondents according to their effectiveness on a scale from 1 (is very effective) to 6 (is totally ineffective). For the illustration in Fig. 6, the results were averaged for each measure and study year. In general, the performed measures in the study subsets were predominantly evaluated to be effective. Averages ranged from 1 to 4, whereby "driving vehicles to a flood-safe place" was the measure with the best evaluations, while "redirecting the water flow" was evaluated by the lowest ranks. Measures aiming at redirecting the water flow and protecting the building against inflowing wa- ter were also considered rather challenging (Fig. 6). We assume that those actions are often difficult to perform, as they require in particular longer times, manpower and know-how. In addition, two different evaluation patterns can be identified within the study subsets. Some measures, e.g. protecting the oil tank or switching off gas/electricity, show a constant improvement in effectiveness over time, whereas almost all other measures were evaluated as being more effective in 2006 and 2011 than in 2005 and 2010.

In 2002, the general picture was very similar to that of the study subsets. People found it most difficult to protect their building and household contents, yet they rated these measures as even more ineffective. The evaluation of other emergency measures resulted in approximately the same ranges as in the other study subsets. However, despite the better knowledge of protection (in comparison to the reference data set of 2002), 2005 and 2010 were years in which the highest percentage of people performed no emergency measures 
Table 8. Reasons why people did not perform emergency measures (multiple answers possible).

\begin{tabular}{lrrrrrr}
\hline Flood event & 2002 & 2005 & 2006 & 2010 & 2011 & Total (2005-2011) \\
\hline It was too late to do anything [\%] & 61 & 65 & 33 & 56 & 35 & 56 \\
Nobody was at home [\%] & 18 & 18 & 25 & 18 & 12 & 18 \\
I did not think the flood would become so severe [\%] & 5 & 12 & 17 & 16 & 0 & 12 \\
I thought emergency measures would be ineffective [\%] & 9 & 5 & 17 & 5 & 12 & 7 \\
I did not know what to do [\%] & 4 & 2 & 0 & 7 & 6 & 4 \\
I was not capable of doing anything [\%] & 3 & 2 & 8 & 0 & 12 & 3 \\
I thought emergency measures wouldn't be necessary [\%] & 9 & $*$ & $*$ & $*$ & $*$ & $*$ \\
Others [\%] & 2 & 3 & 0 & 18 & 24 & 11 \\
No warning [\%] & & 0 & 0 & 12 & 0 & 5 \\
Recently moved in/irresponsible [\%] & & 3 & 0 & 0 & 0 & 1 \\
Not specified/no answer [\%] & 3 & 2 & 0 & 4 & 0 & 2 \\
\hline Number of valid interviews & 284 & 66 & 12 & 57 & 17 & 152 \\
Valid interviews [\%] & 17 & 22 & 8 & 16 & 8 & 15 \\
$\quad$ i.e. people performed no emergency measures) & & & & & & \\
\hline
\end{tabular}

* Data were not requested, since a distinction between "I did not think the flood would become so severe" and "I thought emergency measures would be ineffective" was found to be difficult.

(22 and $15 \%$, respectively). In 2006 and 2011, the fraction of households not performing any emergency measures amounted only to $8 \%$ (Table 8 ). As in 2002 , the main reason for this fact was a lack of time. Respectively, 65 and $56 \%$ of respondents in 2005 and 2010 stated that it was too late to do anything (Table 8). In fact, 45 and $39 \%$ of people in those years argued that they could have done more if they had been warned earlier. In 2006 and 2011, respective percentages were only 23 and $10 \%$ (data not shown).

In summary, it can be said that the warning sources and content have not improved continuously over time. Rather, the regional topography and flood characteristics seem to influence the extent of warnings considerably. This is also reflected by the fact that people affected by floods in 2005 and 2010 had to deal with shorter lead times than people in 2006 or 2011. Hence, the dissemination and quality of (official) flood warnings was limited, with the result that in 2005 and 2010 fewer people knew exactly how to protect themselves. In addition, people affected in 2005 or 2010 were less experienced with floods (see Table 5) and probably less familiar with safeguarding measures. This lack of time, knowledge and experience not only seems to explain why fewer people performed emergency measures in these two study subsets, but also why most of the emergency measures were evaluated as less effective than in 2006 and 2011. Nevertheless, it is apparent that people who were officially warned knew much better how to protect themselves than in 2002. It can therefore be concluded that the flood response capacity of the people had improved after 2002. However, it is still important to further improve early warning systems and communication channels, especially in hilly areas with rapid-onset floods, to enable more people to respond to flood threats.

\subsection{Adverse effects of the flood events}

\subsubsection{Flood damage}

Impacts from flooding can affect different sectors and may have adverse effects on private households (e.g. buildings, furniture), public infrastructure, industrial companies, business interruptions, agriculture, cultural heritage, the environment, or people (e.g. health effects, traumata or even loss of life). These kinds of impacts can be classified into direct or indirect damage, which might be further subdivided into tangible or intangible damage (Messner and Meyer, 2006; Merz et al., 2010). In this study, only direct tangible damage to buildings and contents of private households was analysed.

Looking at all four study subsets, 609 of a total of 1019 respondents $(60 \%)$ suffered damage to residential buildings, and 479 interviewees $(47 \%)$ suffered damage to household contents in terms of repair and replacement costs. Comparison of the single study subsets showed that the shares of people that sustained building losses were about in the same range. The highest percentages were found in $2010(65 \%)$ and the lowest in 2005 (52\%). In 2006 and 2011, 56 and $64 \%$ were recorded, respectively. However, striking differences in values can be identified with respect to household damage. Far fewer people were affected by damages in 2006 and 2011 (31 and 23\%, respectively) than in 2005 and 2010 (51 and $64 \%$, respectively). This reflects the differences in flood characteristics, but also in precautions, warning and responses that were described in the previous sections. The proportion of people suffering building damage in the reference subset 2002 amounted to $64 \%$ and was about equal to that in 2010 and 2011. However, the share of people affected by damage to household contents was the highest, reaching $75 \%$ (data not shown). 
Table 9. Flood damage of buildings.

\begin{tabular}{|c|c|c|c|c|c|c|c|c|}
\hline \multirow[b]{2}{*}{$\begin{array}{l}\text { Flood } \\
\text { event }\end{array}$} & \multicolumn{5}{|c|}{ Excluding flat-rate loss } & \multicolumn{2}{|c|}{ Including flat-rate loss } & \multirow[b]{2}{*}{$\begin{array}{c}\text { Insured mean direct } \\
\text { damage reported in } \\
\text { GDV (2013) [EUR] }\end{array}$} \\
\hline & $n$ & $\begin{array}{r}\text { Mean } \\
\text { damage } \\
\text { [EUR] }\end{array}$ & $\begin{array}{r}\text { Median } \\
\text { damage } \\
\text { [EUR] }\end{array}$ & $\begin{array}{r}\text { Mean damage corrected } \\
\text { by building cost index } \\
\text { (reference year 2013) [EUR] }\end{array}$ & $\begin{array}{r}\text { Median damage corrected } \\
\text { by building cost index } \\
\text { (reference year 2013) [EUR] }\end{array}$ & $n$ & $\begin{array}{r}\text { Minor damage } \\
\text { up to EUR 250 } \\
\text { [\%] }\end{array}$ & \\
\hline 2002 & 1079 & 42093 & 24000 & 52681 & 30037 & 1080 & 3 & 13500 \\
\hline 2005 & 158 & 19302 & 7400 & 23626 & 9058 & 160 & 6 & no data \\
\hline 2006 & 85 & 24814 & 10000 & 30191 & 12167 & 88 & 7 & no data \\
\hline 2010 & 224 & 43695 & 20000 & 46832 & 21436 & 228 & 5 & 14000 \\
\hline 2011 & 119 & 10765 & 2000 & 11369 & 2112 & 133 & 22 & 2100 \\
\hline
\end{tabular}

Table 10. Flood damage of household contents.

\begin{tabular}{|c|c|c|c|c|c|c|c|c|}
\hline \multirow[b]{2}{*}{$\begin{array}{l}\text { Flood } \\
\text { event }\end{array}$} & \multicolumn{5}{|c|}{ Excluding flat-rate loss } & \multicolumn{2}{|c|}{ Including flat-rate loss } & \multirow[b]{2}{*}{$\begin{array}{l}\text { Insured mean direct } \\
\text { damage reported in } \\
\text { GDV (2013) [EUR] }\end{array}$} \\
\hline & $n$ & $\begin{array}{r}\text { Mean } \\
\text { damage } \\
\text { [EUR] }\end{array}$ & $\begin{array}{r}\text { Median } \\
\text { damage } \\
\text { [EUR] }\end{array}$ & $\begin{array}{r}\text { Mean damage corrected } \\
\text { by consumer price index } \\
\text { (reference year 2013) [EUR] }\end{array}$ & $\begin{array}{r}\text { Median damage corrected } \\
\text { by consumer price index } \\
\text { (reference year 2013) [EUR] }\end{array}$ & $n$ & $\begin{array}{r}\text { Minor damage } \\
\text { up to EUR 250 } \\
{[\%]}\end{array}$ & \\
\hline 2002 & 1271 & 16361 & 8500 & 19500 & 10131 & 1276 & 3 & unknown \\
\hline 2005 & 150 & 13418 & 5000 & 15318 & 5708 & 155 & 14 & unknown \\
\hline 2006 & 45 & 12754 & 2000 & 14343 & 2249 & 48 & 13 & unknown \\
\hline 2010 & 222 & 17884 & 10000 & 18886 & 10560 & 224 & 3 & unknown \\
\hline 2011 & 47 & 7957 & 2000 & 8230 & 2069 & 48 & 13 & unknown \\
\hline
\end{tabular}

Tables 9 and 10 list the average financial building and household damage per year, respectively. The proportions of minor damages up to EUR 250 (including flat-rate losses; see Sect. 3) are also specified. The median building damage, given in prices as of 2013 by correcting the actual amounts by the building cost index of June 2013 (DESTATIS, 2014a), was highest in 2010 and lowest in 2011, reaching EUR 21436 and 2112, respectively. The corresponding median loss in 2002 amounted to EUR 30037 (Table 9). A classification of these damages can be seen in Fig. 7. It is noteworthy that in 2011 the share of damage up to EUR 5000 accounted for about two-thirds of all reported damages. In the other three study years, this proportion did not even cover half of the damages, but higher costs were more often reported.

Median damages of household contents in prices as of June 2013, corrected by the consumer price index (DESTATIS, 2014b), were much lower than building damages. However, the highest and lowest losses were again recorded in 2010 and 2011 and amounted to EUR 10560 and 2069, respectively. The median loss of household contents in 2002 amounted to EUR 10131 and was comparable to 2010 (Table 10). In contrast to the classification of building damages, the share of damages to household contents up to EUR 5000 was highest in the study subsets $2006(70 \%)$ and $2011(64 \%)$ and reached nearly $50 \%$ in 2005 . Only in 2010 was this proportion merely $33 \%$, which in turn indicates a large number of higher damages (see Fig. 8).

In summary, the median losses show that the highest damages were always recorded in 2010 (and 2005, with regard to household contents) and the lowest in 2011 (and 2006,

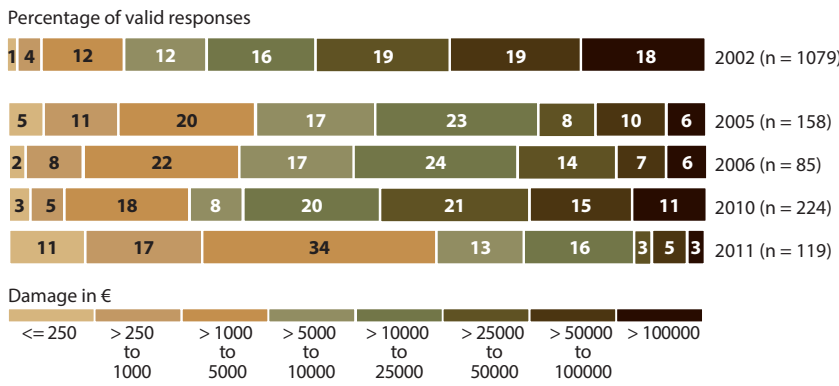

Figure 7. Classified damage to residential buildings (excluding minor damage flat-rate), prices as of June 2013.

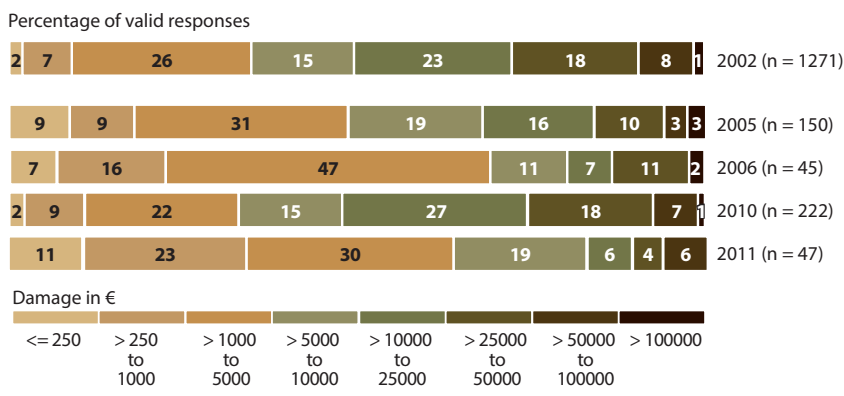

Figure 8. Classified damage to household contents (excluding minor damage flat-rate), prices as of 2013.

with regard to household contents). This pattern can only be explained by taking into account several factors, e.g. flood characteristics, flood experience, awareness and precaution. Hence, losses were higher the shorter the lead time, the lower 

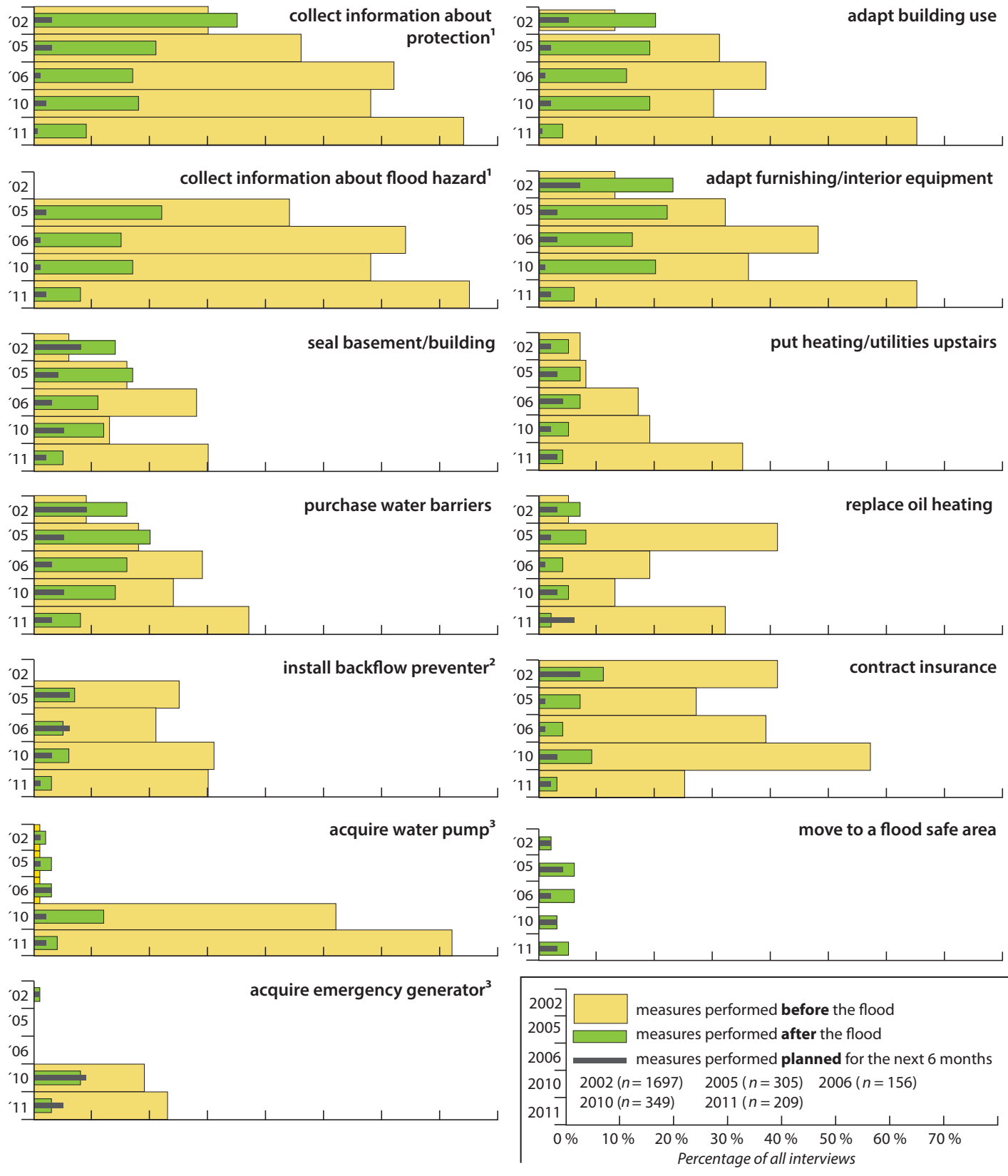

in 2002, collection of information about protection and flood hazard have not been requested individually but summarized in category "collect information about protection". ${ }^{2}$ measures were not explicitly requested in 2002 but deduced from open answers.

${ }^{3}$ measures were not explicitly requested in 2002, 2005 and 2006 but deduced from open answers.

Additionally, no distinction was made between acquisition of pumps and emergency generators. Measures were therefore summarized in the category"acquire water pump".

Figure 9. Precautionary measures taken in private households before and after the respective flood events, and measures planned for the next six months.

the previous flood experience and perceived probability of being potentially affected, the lower the amount of knowledge about how to protect oneself and the lower the precaution level. However, these interdependencies apply to damages to household contents, yet are only partly explain the building damages.
Besides this, the expected trend is that households with lower losses recover faster after the flood. This assumption will be addressed in the following section.

\subsubsection{Recovery}

In this study, the recovery status is a simplified measure for the regained standard of living after a flood event compared 
to the status before the event, knowing that the recovery process in fact needs to be seen in a more nuanced light and is influenced by several factors (e.g. Whittle et al., 2010).

In the surveys, respondents were asked to assess the state of their building and contents at the time of the interview compared to their state before the flood on a scale from 1 (is building/household contents is completely restored/replaced) to 6 (is there is still considerable damage to the building/household contents). For the analyses, the flood events investigated were divided into two groups as described in Sect. 3.2. The comparison between the flood events in 2006 and 2002 8-10 months after the flood showed that in 2006, the building and furniture status had been valued at 1 or 2 by 62 and even $73 \%$ of interviewees, respectively. Thus, people recovered faster than in 2002, where the equivalent shares amounted only to 46 and $59 \%$, respectively. The comparison between the flood events in 2005, 2010 and 2011 1318 months after the floods reveals that, although the time interval between the 2011 flood and the survey was the shortest among the three events (13-14 months), respondents always recovered the best. $77 \%$ of people stated a very good or good building status. In 2005 and 2010, however, these percentages were 67 and $62 \%$, respectively. The corresponding shares concerning the recovery of the household contents in 2011, 2010 and 2005 were even higher, reaching 82, 72 and $64 \%$, respectively.

The expected trend that households with lower losses recover faster after the flood could be confirmed for building damages and partly for furnishing damages, as can be clearly seen in the results of the study subset 2011 . However, the amount of loss is not the only factor that influences recovery. For example, flood insurance or the receipt of government compensation payments might also play a decisive role in this context. This has not been investigated in this study, however, yet will be a subject of further analyses.

\subsection{Lessons learned - will people be better prepared for future floods?}

Finally, the question arises whether the recent flood experience motivated people to perform (more) risk reduction measures shortly after the flood or in the near future. Therefore, respondents were asked whether they had implemented any precautionary measures after the flood or whether they were planning to take some within the next six months. The results are shown in Fig. 9. To enable comparability, measures that were only mentioned in open answers were not included in this analysis.

Private flood prevention improved after each flood event of the study subsets, especially after 2005 and 2010 (Fig. 9). After these two years, precautionary measures like the sealing of the basement/building, the purchasing of water barriers and the adaptation of furnishing/interior equipment or building use increased the most (between 56 and 113\%). After 2006, though, only the purchasing of water barriers increased by more than $50 \%$ and after 2011, no measure improved by more than $25 \%$. The lower values of the latter two study subsets might be explained by the fact that flood precaution was already at a much higher level before the respective events (see Sect. 4.2, Fig. 2). In comparison, after 2002 almost all measures more than doubled, but started from a considerably lower level.

Between 2005 and 2011, the maximum proportion of planned measures within the next six months amounted to $6 \%$ and was approximately in the same range as in 2002. However, about $8 \%$ of all households interviewed decided to move to a flood-safe area or at least planned to do so in the near future. In 2002, this share was only $3 \%$. This slight increase seems to be consistent with media reports, in which retreat/resettlement is felt to be mentioned more often as a risk reduction measure than ten years ago. This aspect has to be investigated in the future.

The overall results clearly show that the risk awareness of most affected households increased after the 2002 flood event. This led to an increased implementation of additional measures, particularly in years with a previous low precaution level. A positive development is that mainly building retrofitting and adaptation of building and furnishing use improved, as these kinds of damage reduction measures are considered particularly effective (Kreibich et al., 2005). Nevertheless, these percentages still have to be increased, as the study subset of 2011 reveals that a higher level of private precaution can be achieved.

\section{Conclusions and recommendations}

During the flood in 2002, people's ability to cope with the flood was low, resulting in high building and content losses. Since many governmental activities to improve flood protection, awareness and precaution have been undertaken, the question arose as to how residents reacted during recent flood events between 2005 and 2011. In general, this study shows that much has been achieved since 2002; however, there is still much room for further improvements. Figure 10 provides a qualitative overview of all results obtained in this study.

In particular the state of private precaution increased after the 2002 flood. Only about $7 \%$ of all households interviewed had not performed any precautionary measure. The best precautions were performed before the flood events in 2011 and 2006, which might be explained by more flood experience and overall greater risk awareness of the residents. However, on average $53 \%$ of all respondents had only taken information precautions or participated in networks, which does not lead to damage reduction per se. Accordingly, investments in flood-proofing or retrofitting measures still need to be stimulated in order to reduce future damage more efficiently.

Early warnings and emergency responses were apparently strongly dependent on the floods' characteristics and 


\begin{tabular}{rr|r|r|r|r|r|r|} 
Section & \multicolumn{2}{|c|}{ Results } & 2002 & 2005 & 2006 & 2010 & 2011 \\
\hline 4.2. & Preparedness level & low & medium & high & medium & high \\
\hline $4.3 .1,4.3 .2$ & Warning & bad & medium & good & medium & good \\
\hline 4.3 .3 & Response & medium & medium & good & medium & good \\
\hline 4.4 .1 & Damage & high & medium & medium & high & low \\
\hline 4.4 .2 & Recovery & slow & slow & medium & slow & fast \\
\hline 4.5 & Post-flood precaution improvement & high & high & medium & high & low \\
\hline
\end{tabular}

Figure 10. Qualitative summary of all results.

the regional topography, but were also influenced by previous flood experiences of the respondents. Therefore, a constant improvement over the years could not be observed, but rather corresponding results of flood events in 2005 and 2010 tended to be lower than those in 2006 and 2011. Hence, it is important to further improve early warning systems and communication channels, especially in hilly areas with rapidonset floods, to enable more people to respond to the threat of flooding.

Flood losses and recovery status also seem to be influenced by the flood's characteristics. The overall improved flood precautions and the larger share of people knowing how to protect themselves could only counteract damages to a certain extent. However, flood damages are most likely the result of additional influencing factors. Accordingly, more detailed studies are needed to investigate essential key factors to estimate and describe flood damages more precisely.

After the flood event, respondents became more aware of their risk exposure and were motivated to invest in floodproofing and building retrofitting measures in the future. Yet, the challenge remains of increasing the precaution level of private households, especially in areas with low previous flood experience and risk awareness.

Generally, most studies on flood damages deal with residential flood damages. As flood damage mitigation related to businesses is considered less frequently, it would be interesting to carry out a further survey to analyse whether the same results that were found in this study can also be found for businesses. Moreover, investigations of this study were primarily descriptive. For future investigations, it would therefore be interesting to focus on individual key factors and to apply multivariate statistics or theory- or model-based analyses. To give an example, it is known that flood experience is an important precondition for the implementation of precautionary measures. But there are studies that question the importance of the relationship between risk awareness and the adoption of private mitigation measures and assume other factors to be more influential (Bubeck et al., 2012a; Scolobig et al., 2012; Wachinger et al., 2013), e.g. policy changes, people's perception regarding their responsibility for flood protection, trust in public flood protection, severity of the adverse flood consequences experienced, negative emotions, coping appraisal or socio-economic and geographic variables (Grothmann and Reusswig, 2006; Siegrist and Gutscher,
2008; Botzen et al., 2009; Zaalberg et al., 2009; Kreibich et al., 2011; Terpstra, 2011). Therefore, more detailed investigations are needed to analyse what (other) factors influence people's precautionary behaviour. This could optionally be examined on the basis of the protection motivation theory introduced by Rogers (1975).

Furthermore, some factors seem to be mainly influenced by the affected region. For example, precautionary behaviour might be attributed to a certain "risk culture" (culture of selfprotection) in some regions in Germany, where a more natural interaction with the hazard and a better awareness of the overall risk has been indicated (Bubeck et al., 2012b). In contrast, other variables such as flood warning (lead time) seem to be predominantly influenced by the flood event and its flow characteristics (intensity, velocity of onset, etc.). These aspects also have to be investigated in more detail in the near future. And finally, based on these results, it should be investigated how flood damage models can be improved.

Acknowledgements. The present work was partly developed within the framework of the Panta Rhei Research Initiative of the International Association of Hydrological Sciences (IAHS). The two surveys were conducted within the MEDIS project funded by the German Ministry for Education and Research (BMBF; no. 0330688) and by a joint venture between the University of Potsdam, the GeoForschungsZentrum Potsdam and the Deutsche Rückversicherung AG, Düsseldorf, respectively. Data analysis was supported by the BMBF project no. 13N13017. We are furthermore indebted to Ute Dolezal (University of Potsdam) for the graphic design of all figures.

Edited by: P. Tarolli

Reviewed by: three anonymous referees 


\section{References}

Axer, T., Bistry, T., Klawa, M., Müller, M., and Süßer, M.: Sturmdokumentation 2011 Deutschland, Deutsche Rück, Düsseldorf, 2012 (in German).

BfG (Federal Institute of Hydrology): Das Hochwasser der Elbe im Frühjahr 2006, BfG-1514, Koblenz, Germany, 2006 (in German).

BiB (Federal Institute for Population Research): Durchschnittsalter der Bevölkerung, available at: http://www.bib-demografie. de/SharedDocs/Glossareintraege/DE/D/durchschnittsalter_ bevoelkerung.html?nn=3074114, last access: 7 April, 2014a (in German).

BiB (Federal Institute for Population Research): Haushaltsstrukturen, available at: http://www.bib-demografie.de/SharedDocs/ Publikationen/DE/Download/Abbildungen/13/Daten/a_13_02_ durchschnittl_hhgroesse_d_1991_2030_daten.html;jsessionid= 665926462F33BE3D236CF56C95326F7F.2_cid292?nn= 3081858, last access: 7 April, 2014b (in German).

BMVBS (Federal Ministry of Transport, Building and Urban Development): Hochwasserschutzfibel, Bauliche Schutz- und Vorsorgemaßnahmen in hochwassergefährdeten Gebieten, available at: http://www.bbsr.bund.de/BBSR/DE/Veroeffentlichungen/BMVBS (last access: 1 March 2015), Vol. 2, Berlin, 2008 (in German).

Botzen, W. J. W., Aerts, J. C. J. H., and van den Bergh, J. C. J. M.: Willingness of homeowners to mitigate climate risk through insurance, Ecol. Econ., 68, 2265-2277, 2009.

Bubeck, P., Botzen, W. J. W., and Aerts, J. C. J. H.: A review of risk perceptions and other factors that influence flood mitigation behaviour, Risk. Anal., 32, 1481-1495, 2012a.

Bubeck, P., Botzen, W. J. W., Kreibich, H., and Aerts, J. C. J. H.: Long-term development and effectiveness of private flood mitigation measures: an analysis for the German part of the river Rhine, Nat. Hazards Earth Syst. Sci., 12, 3507-3518, doi:10.5194/nhess-12-3507-2012, 2012 b.

Bürgi, T.: Operational flood forecasting in mountainous areas - An interdisciplinary challenge, International Conference in Flood Estimation, Bern, Switzerland, 6-8 March 2002, 397-406, 2002.

de Bruijn, K. M.: Resilience and flood risk management, A systems approach applied to lowland rivers, $\mathrm{PhD}$ thesis, Delft University, the Netherlands, 2005.

DESTATIS (Federal Statistical Office): Statistisches Jahrbuch - Deutschland und Internationales 2013, available at: https: //www.destatis.de/DE/Publikationen/StatistischesJahrbuch/ StatistischesJahrbuch2013.pdf?_blob=publicationFile (last access: 20 May 2014), 2013 (in German).

DESTATIS (Federal Statistical Office): Preisindizes für die Bauwirtschaft, Februar 2014 (1. Vierteljahresausgabe), Fachserie 17, Reihe 5, available at: https: //www.destatis.de/DE/Publikationen/Thematisch/Preise/ Baupreise/BauwirtschaftPreise2170400143214.pdf?_blob= publicationFile, last access: 1 June, 2014a (in German).

DESTATIS (Federal Statistical Office): Preise - Verbraucherpreisindizes für Deutschland, Jahresbericht 2013, available at: https://www.destatis.de/DE/Publikationen/Thematisch/Preise/ Verbraucherpreise/VerbraucherpreisindexJahresberichtPDF_ 5611104.pdf?_blob=publicationFile, last access: 1 June, 2014b (in German).

DKKV (German Committee for Disaster Prevention): Hochwasservorsorge in Deutschland - Lernen aus der Katastrophe 2002 im
Elbegebiet, DKKV-Report 29, Bonn, Germany, 2003 (in German).

EC (European Commission): Directive 2007/60/EC of the European Parliament and of the Council of 23 October 2007 on the assessment and management of flood risks, available at: http://eur-lex.europa.eu/LexUriServ/LexUriServ.do?uri= OJ:L:2007:288:0027:0034:EN:PDF (last access: 1 June 2013), 2007.

EC (European Commission): Study on Economic and Social Benefits of Environmental Protection and Resource Efficiency Related to the European Semester, Annex 1: Country Fiches, Brussels, Belgium, 701 pp., 2014.

EM-DAT (OFDA/CRED International Disaster Database): Top 10 Natural Disasters in Germany for the period 1900 to 2014, Université Catholique de Louvain, Brussels, Belgium, available at: www.emdat.be, last access: 5 June, 2014.

Engel, H.: The flood event 2002 in the Elbe river basin: causes of the flood, its course, statistical assessment and flood damages, Houille Blanche, 6, 33-36, 2004.

FEMA (Federal Emergency Management Agency): About FEMA What we do, available at: http://www.fema.gov/about-fema (last access: 3 December 2013), 2004.

GDV (German Insurance Association): Online-Serviceteil zum Naturgefahrenreport 2013, available at: http://www.gdv.de/ wp-content/uploads/2013/10/GDV-Naturgefahrenreport2013_ Online-Serviceteil.pdf, last access: 3 December, 2013 (in German).

Golding, B. W.: Review - Long lead time flood warnings: reality or fantasy?, Meteorol. Appl., 16, 3-12, 2009.

Grothmann, T. and Reusswig, F.: People at risk of flooding: Why some residents take precautionary action while others do not, Nat. Hazards, 38, 101-120, 2006.

ICPR (International Commission for the Protection of the Rhine): Non-structural flood plain management - Measures and their effectiveness, ICPR-Report, Koblenz, Germany, 2002.

IKSE (International Commission for the Protection of the Elbe River): Hydrologische Auswertung des Frühjahrshochwassers 2006 im Einzugsgebiet der Elbe, Report, IKSE, Magdeburg, Germany, 2007 (in German).

Jelonek, L., Wrzeszcz, L., Zawiślak, J., Walther, P., Winkler, U., Wortha, S., Srejber, J., and Petr, J.: Gemeinsamer polnischdeutsch-tschechischer Bericht zum Hochwasser vom 07. bis 10. August 2010 an der Lausitzer Neisse als Bestandteil der vorläufigen Risikobewertung gemäß Artikel 4 der Hochwasserrisikomanagementrichtlinie (2007/60/EG), Report Wrocław, Dresden, Prag, available at: http://www.umwelt.sachsen.de/umwelt/ wasser/download/06-12-10_LN_dt.pdf (last access: 22 January 2014), 2010 (in German).

Kienholz, H., Krummenacher, B., Kipfer, A., and Perret, S.: Aspects of integral risk management in practice-considerations with respect to mountain hazards in Switzerland, Österreichische Wasser- und Abfallwirtschaft, 56, 43-50, 2004.

Korndörfer, C., Rümpel, A., Seifert, J. O., Kroll, H., Grebedünkel, D., Jakob, T., Frenzel, F., and Ullrich, H.: Bericht zum Frühjahrshochwasser 2006, Report of the Umweltamt Dresden (Environmental Agency of Dresden), Dresden, Germany, 2006 (in German).

Kott, K. and Behrends, S.: Einnahmen und Ausgaben privater Haushalte, Ergebnisse der Einkommens- und Verbrauchsstich- 
probe 2008, Federal Statistical Office, Wirtschaft und Statistik, 15, 465-484, 2011 (in German).

Kreibich, H. and Thieken, A. H.: Coping with floods in the city of Dresden, Germany, Nat. Hazards, 51, 423-436, 2009.

Kreibich, H., Thieken, A. H., Petrow, Th., Müller, M., and Merz, B.: Flood loss reduction of private households due to building precautionary measures - lessons learned from the Elbe flood in August 2002, Nat. Hazards Earth Syst. Sci., 5, 117-126, doi:10.5194/nhess-5-117-2005, 2005.

Kreibich, H., Müller, M., Thieken, A. H., and Merz, B.: Flood precaution of companies and their ability to cope with the flood in August 2002 in Saxony, Germany, Water Resour. Res., 43, W03408, doi:10.1029/2005WR004691, 2007.

Kreibich, H., Seifert, I., Thieken, A. H., Lindquist, E., Wagner, K., and Merz, B.: Recent changes in flood preparedness of private households and businesses in Germany, Reg. Environ. Change, 11, 59-71, 2011.

Kron, W.: Überschwemmungsüberraschung: Sturzfluten und Überschwemmungen fernab von Gewässern, Wasserwirtschaft, 6, 1520, 2009 (in German).

Kron, W. and Ellenrieder, T.: Zunehmende Wetterschäden: Was kostet das die Versicherungswirtschaft? Teil 1: Wetterkatastrophen - Ursachen und Schäden, Korrespondenz Wasserwirtsch., 1, 691-696, 2008 (in German).

Kuhlicke, C., Begg, C., Beyer, M., Callsen, I., Kunath, A., and Löster, N.: Hochwasservorsorge und Schutzgerechtigkeit: Erste Ergebnisse einer Haushaltsbefragung zur Hochwassersituation in Sachsen. UFZ Discussion Papers 15/2014. Fachbereich Sozialwissenschaften, available at: http://www.ufz.de/export/data/ global/59629_DP_15_2014_Kuhlicke_Hochwasservorsorge.pdf (last access: 15 January 2015), 2014 (in German).

LAWA (German Working Group of the Federal States on Water Issues): Leitlinien für einen zukunftsweisenden Hochwasserschutz: Hochwasser - Ursachen und Konsequenzen, Länderarbeitsgemeinschaft Wasser, Stuttgart, Germany, 1995 (in German).

LfU (Bavarian Environment Agency): August-Hochwasser 2005 in Südbayern, Bayerisches Landesamt für Umwelt, Augsburg, Germany, 2006 (in German).

LfU (Bavarian Environment Agency): Gewässerkundlicher Bericht Hochwasser August 2005, Bayerisches Landesamt für Umwelt, Augsburg, Germany, 2007 (in German).

LfU (Bavarian Environment Agency): Junihochwasser 2013 Wasserwirtschaftlicher Bericht, Augsburg, Germany, 2014 (in German).

LHW (State office for flood control and water management of Saxony-Anhalt): Bericht über das Hochwasser Januar 2011, Landesbetrieb für Hochwasserschutz und Wasserwirtschaft SachsenAnhalt, Magdeburg, Germany, 2011 (in German).

Lindell, M. K. and Hwang, S. N.: Households perceived personal risk and responses in a multihazard environment, Risk Anal., 28, 539-556, 2008.

Merz, B., Kreibich, H., Schwarze, R., and Thieken, A.: Review article "Assessment of economic flood damage", Nat. Hazards Earth Syst. Sci., 10, 1697-1724, doi:10.5194/nhess-10-16972010, 2010.

Messner, F. and Meyer, V.: Flood damage, vulnerability and risk perception - Challanges for flood damage research, in: Flood risk management: Hazards, vulnerability and mitigation mea- sures, edited by: Schanze, J., Zeman, E., and Marsalek, J., NATO Science Series, 67, 149-167, 2006.

Molinari, D., Ballio, F., and Menoni, S.: Modelling the benefits of flood emergency management measures in reducing damages: a case study on Sondrio, Italy, Nat. Hazards Earth Syst. Sci., 13, 1913-1927, doi:10.5194/nhess-13-1913-2013, 2013.

Mudelsee, M., Börngen, M., Tetzlaff, G., and Grünewald, U.: Extreme floods in central Europe over the past 500 years: Role of cyclone pathway "Zugstrasse Vb", J. Geophys. Res., 109, D23101, doi:10.1029/2004JD005034, 2004.

Müller, M.: Die Auswirkungen von Deichbrüchen und Heizöllagerung auf Überschwemmungsschäden bei Wohngebäuden, Versicherungswirtschaftm 151, 693-696, 2000 (in German).

Parker, D. J.: Floods, Vol. 1, Routledge, London, UK, 431 pp., 2000.

PLANAT (National Platform for Natural Hazards): The cycle of integrated risk management, available at: http://www.planat.ch/ en/specialists/risk-management/ (last access: 10 January 2014), 2004.

Rogers, R. W.: A protection motivation theory of fear appeals and attitude change, J. Psychol., 91, 93-114, 1975.

Schwarze, R., Schwindt, M., Weck-Hannemann, H., Raschky, P., Zahn, F., and Wagner, G. G.: Natural Hazard Insurance in Europe: Tailored Responses to Climate Change are Needed, Environ. Policy Gov., 21, 18-30, 2011.

Scolobig, A., de Marchi, B., and Borga, M.: The missing link between flood risk awareness and preparedness: Findings from case studies in an Alpine Region, Nat. Hazards, 63, 499-520, 2012.

Siegrist, M. and Gutscher, H.: Flooding risks: A comparison of lay people's perceptions and expert's assessments in Switzerland, Risk Anal., 26, 971-979, 2006.

Siegrist, M. and Gutscher, H.: Natural hazards and motivation for mitigation behaviour: People cannot predict the affect evoked by a severe flood, Risk Anal., 28, 771-778, 2008.

Silver, M. L.: International best practices in disaster mitigation and management recommended for Mongolia, UNDP, Disaster Management Conference, Ulaanbaatar, Mongolia, 4 December 2001, $1-9,2001$.

Takao, K., Motoyoshi, T., Sato, T., and Fukuzono, T.: Factors determining residents' preparedness for floods in modern megalopolises: the case of the Tokai flood disaster in Japan, J. Risk Res., 7, 775-787, 2004.

Terpstra, T.: Emotions, trust, and perceived risk: affective and cognitive routes to flood preparedness behaviour, Risk Anal., 31, 1658-1675, 2011.

Thieken, A. H., Müller, M., Kreibich, H., and Merz, B.: Flood damage and influencing factors: New insights from the August 2002 flood in Germany, Water Resour. Res., 41, W12430, doi:10.1029/2005WR004177, 2005.

Thieken, A. H., Petrow, Th., Kreibich, H., and Merz, B.: Insurability and mitigation of flood losses in private households in Germany, Risk Anal., 26, 383-395, 2006.

Thieken, A. H., Kreibich, H., Müller, M., and Merz, B.: Coping with floods: preparedness, response and recovery of flood-affected residents in Germany in 2002, Hydrolog. Sci. J., 52, 1016-1037, 2007.

Ulbrich, U., Brücher, T., Fink, A. H., Leckebusch, G. C., Krüger, A., and Pinto, J. G.: The central European floods of August 2002: Part 1 - Rainfall periods and flood development, Weather, 58, 371-376, 2003. 
Vis, M., Klijn, F., de Bruijn, K. M., and van Buuren, M.: Resilience strategies for flood risk management in the Netherlands, Int. J. River Basin Management, 1, 33-40, 2003.

Wachinger, G., Renn O., Begg, C., and Kuhlicke C.: The risk perception paradox - Implications for governance and communication of natural hazards, Risk Anal., 33, 1049-1065, 2013.

Walther, P., Görner, C., Gerber, S., and Wundrak, P.: Ereignisanalyse der Hochwasser von 2010 und 2011 - meteorologische und hydrologische Ursachen, Prozesse, Schäden und Lehren, in: Wasserbaukolloquium 2013: Technischer und organisatorischer Hochwasserschutz - Bauwerke, Anforderungen, Modelle, Dresdner Wasserbauliche Mitteilungen, Dresden, Germany, 48, 141148, 2013 (in German).

Weinstein, N. D., Rothman, A. J., and Nicolich, M.: Use of correlational data to examine the effects of risk perceptions on precautionary behaviour, Psychol. Health, 13, 479-501, 1998.
Whittle, R., Medd, W., Deeming, H., Kashefi, E., Mort, M., Twigger Ross, C., Walker, G., and Watson, N.: After the rain - Learning the lessons from flood recovery in Hull, Final Project Report for Flood, Vulnerability and Urban Resilience: a real-time study of local recovery following the floods of June 2007 in Hull, Lancaster University, Lancaster, UK, 2010.

Younis, J., Anquetin, S., and Thielen, J.: The benefit of highresolution operational weather forecasts for flash flood warning, Hydrol. Earth Syst. Sci., 12, 1039-1051, doi:10.5194/hess-121039-2008, 2008.

Zaalberg, R., Midden, C., Meijnders, A., and McCalley, T.: Prevention, adaptation, and threat denial: Flooding experiences in the Netherlands, Risk Anal., 29, 1759-1778, 2009. 